\title{
25 Research Soure \\ The Life Buried in the Sediment of an Invasive Red Macroalga Colonizing Saltmarshes
}

\section{Gwladys Surget}

Universite de Bretagne Occidentale

Klervi Le Lann

Universite de Bretagne Occidentale

Nelly Kervarec

Universite de Bretagne Occidentale

\section{Maëla Semery}

Universite de Bretagne Occidentale

\section{Solène Connan}

Universite de Bretagne Occidentale

\section{Gaspard Delebecq}

Universite de Bretagne Occidentale

\section{Marie-Aude Poullaouec}

Universite de Bretagne Occidentale

Isabelle Bihannic

Universite de Bretagne Occidentale

Dominique Davoult

Sorbonne Université: Sorbonne Universite

\section{Nathalie Poupart}

Universite de Bretagne Occidentale

Valérie STIGER-POUVREAU ( $\nabla$ valerie.stiger@univ-brest.fr)

Université de Bretagne Occidentale: Universite de Bretagne Occidentale https://orcid.org/0000-00033041-0468

\section{Research Article}

Keywords: Agarophyton vermiculophyllum, alien red seaweed, burial tolerance, chlorophyll fluorescence, fragmentation and dispersal, osmolytes and pigments contents

Posted Date: March 2nd, 2022

DOI: https://doi.org/10.21203/rs.3.rs-1276307/v1 
License: (c) (i) This work is licensed under a Creative Commons Attribution 4.0 International License. Read Full License 


\section{Abstract}

Originating from Japan, the red macroalga Agarophyton vermiculophyllum colonizes saltmarshes from Europe and is invasive in mudflats from Brittany (France) where it creates a novel habitat with a high associated animal diversity. In Brittany, its particularity to bury in the mud, led us to wonder whether the buried fragments were still alive or just detritus. The seasonal phenology of buried fragments was monitored, together with the physiological state of fragments using Imaging-PAM fluorometry and respiration measurements. In parallel, metabolomic analyses allowed the analyses of the major intracellular metabolites. At depth in the mud, siltation is responsible for a fragmentation of the thallus and biochemical variations. A strong increase of antheraxanthin and zeaxanthin, chlorophyll- $a$ and $\beta$ carotene was noticed while the R-Phycorythrine decreased. For osmolytes, we noted an alanine increase with siltation while floridoside decreased. No variation was noticed for isethionic acid and taurine. The $\mathrm{C} / \mathrm{N}$ ratio was higher at the silt surface and decreased with siltation. Finally, The fragments are physiologically active; they present functional photosystems II and therefore do not consist of detrital material. Our study shows the ability of thalli to live in the mud to a depth of $12 \mathrm{~cm}$. Fragmentation of the thallus is probably due to grazing intensity and bioturbation activity. Finally, the existence of small viable fragments deep in the mud, may represent a reserve biomass and considerably favors the propagation of Agarophyton vermiculophyllum, on the same site but may also allow a migration of the species through sediment transport.

\section{Introduction}

Agarophyton vermiculophyllum (Ohmi) Papenfuss, previously known as Gracilaria vermiculophylla (Ohmi) Papenfuss (Gurgel et al. 2018), represents one of the most invasive seaweed species with a large distribution all around the world (Bellorin et al. 2004; Rueness 2005; Thomsen et al. 2007, 2013; Weinberger et al. 2008; Saunders 2009; Sfriso et al. 2010, 2020; Hu and Juan 2013; Nettleton et al. 2013; Stiger-Pouvreau and Thouzeau 2015; Krueger-Hadfield et al. 2017; Ramus et al. 2017; Surget et al. 2017; Bonthond et al. 2020; Bermejo et al. 2020). This agarophyte belongs to the Order Gracilariales and Family Gracilariaceae, and is an euryhaline and eurythermal species (Yokoya et al. 1999; Kameyama et al. 2021) that has the ability to colonize mainly unvegetated mudflat such as the low part of saltmarshes (slikke) of shallow and sheltered estuaries. This engineer macroalga, native from Northwest Pacific and now worldwide introduced, has invaded estuarine mudflats in Brittany (France) since 1996 (Rueness 2005) and has successfully expanded along the North western coasts of Europe in few years (Rueness 2005; Guillemin et al. 2008; Weinberger et al. 2008; Abreu et al. 2011). Its introduction in a new area leads to multiple ecological consequences and modifies in depth invaded ecosystems (Hu and Juan 2013). Once established, this invader may modify the metabolism of the mudflat ecosystem (Davoult et al. 2017; Volaric et al. 2019), induce structural changes of the mud (Besterman et al.,2021) with consequences on the foraging behaviour of shorebirds (Besterman et al. 2020), compete with native macrophytes (Martínez-Lüscher and Holmer, 2010; Nettleton et al. 2013; Thomsen et al. 2013), modify macrofauna richness and abundance (Weinberger et al. 2008; Johnston and Lipcius 2012; Ramus et al. 2017; Davoult 
et al. 2017), transform food web up to biogeochemical fluxes (Byers et al. 2012; Ramus and Long 2016; Davoult et al. 2017) and also could impact sessile organism recruitments on hard-bottom assemblage such as oyster reefs in muddy estuaries (Thomsen and McGlathery 2006), increasing then the ecosystem multifunctionality (Thomsen et al. 2019). This red macroalga exhibits multiple phenological variations depending on the characteristics of its introduced area. The alga may form perennial mats of either loose-lying thalli potentially issued of drifting fragments like in Denmark (Thomsen and McGlathery 2006), or mats of entangled fragments as in Brittany (Surget et al. 2017), or the alga may be attached to worm tubes built by Diopatra cuprea and/or bivalve shells as it is visible for populations in Denmark and Portugal (Thomsen and McGlathery 2005; Abreu et al. 2011). Interestingly, this high phenotypic diversity was associated with a low genetic diversity in introduced populations compared to the native one, potentially due to a unique donor region in the native area which seems to be the East of the Japan Sea (Kim et al. 2010; Krueger-Hadfield et al. 2021). It was hypothesized a genotype selection with low palatability character during introduction events (Hammann et al. 2013; Wang et al. 2021).

Agarophyton vermiculophyllum has no native analogue in Brittany rias, as already reported on mudflats of Georgia and South Carolina (Byers et al. 2012). However, on specific areas in the Bay of Brest, $A$. vermiculophyllum coexists with the invasive seagrass Spartina alterniflora in the highest mudflat zone and the low saltmarshes. In a previous study, we reported a spectacular fragmented phenotype of $A$. vermiculophyllum in rias of the Bay of Brest (Surget et al. 2017) which went along with a burial. The sinking in sediment of $A$. vermiculophyllum individuals was reported in previous studies carried out in Denmark (Thomsen et al. 2007; Thomsen and McGlathery 2007), where authors supposed a physiological tolerance of the species to burial. Nevertheless, thorough studies were not conducted on in situ populations of $A$. vermiculophyllum concerning this particular behavior. Previous studies gave however insights on physiological tolerances of $A$. vermiculophyllum to burial: this invader is well adapted to brackish water (Weinberger et al. 2008) and not sensitive to prolonged periods of darkness longer than five months (Nyberg and Wallentinus 2009) and unattached small fragments could easily grow (Rueness 2005; Nyberg 2007). Kameyama et al. (2021) demonstrated the eurythermal and euryhaline performances of native populations of $A$. vermiculophyllum together with a potential tolerance to desiccation and high irradiance. Nevertheless, concerning this particular behavior of burial, thorough studies were not conducted on in situ populations.

Few examples of macrophyte resistance to natural burial were described in the literature. In a brackish lagoon (Veerse Meer lagoon) in the Netherlands, the burial during Winter of Ulva spp. allows the macroalgae to resist to cold temperatures during the unfavorable season, and is followed by events of fragments liberation from sediment, which finally triggers a spring bloom mainly contributing to a summer explosion of biomasses (Kamermans et al. 1998). Additionally, Glasby et al. (2005) investigated the resilience such as the recovery rate of buried thalli of another green macroalga, Caulerpa taxifolia, and concluded to an underestimation of the species distribution range linked to its burial resistance. Another example is sporophytes of the brown macroalga Saccharina latissima which could be buried under sediment by local hydrodynamic processes in Helgoland (Roleda and Dethleff 2011). 
In this context, the tolerance to burial in sediment of the red macroalga Agarophyton vermiculophyllum was seasonally monitored during a year in saltmarshes from Brittany (France). We hypothesized a perennial occurrence of this invasive red macroalga buried into the mud, not only as detrital organic matter but as living fragments under a state of "dormancy". The objective of this study was to investigate the seasonal phenology of buried fragments in terms of biomass and size classes and to determine physiological evidence of the living state of this silted biomass via chlorophyll fluorescence records using imaging pulse amplitude modulated (Imaging-PAM) fluorometry and respiration measurements. In addition, with the aim to have an overview of $A$. vermiculophyllum acclimation to burial, further biochemical analyses were conducted. Metabolite modification in response to burial was explored through metabolomic analyses using quantitative ${ }^{1} \mathrm{H}$ nuclear magnetic resonance ( ${ }^{1} \mathrm{H}$ qNMR), allowing the identification and also the quantification of the major intracellular metabolite solutes. Pigment quantification by high pressure liquid chromatography (HPLC) or by spectrophotometry according to pigments was also performed to observe the acclimation of this invasive macrophyte to darkness and anaerobic conditions induced by burial. The response to burial by $A$. vermiculophyllum will be discussed by integrating these ecological, ecophysiological and metabolomic data derived from our monitoring field study.

\section{Materials And Methods}

\section{Ecological monitoring}

The ecological monitoring was performed in mudflats of three different rias located in the Bay of Brest (Brittany, France) named as Moulin $\left(48^{\circ} 21.490^{\prime} \mathrm{N}-4^{\circ} 20.447^{\prime} \mathrm{W}\right)$, Penfoul $\left(48^{\circ} 21.619^{\prime} \mathrm{N}-4^{\circ} 19.186^{\prime} \mathrm{W}\right)$ and Faou $\left(48^{\circ} 21.497^{\prime} \mathrm{N}-4^{\circ} 20.444^{\prime} \mathrm{W}\right)$. Samplings and measurements were carried out during low tides, every three months from December 2013 to December 2014, in parallel to the monitoring performed by Surget et al. (2017).

Algal thalli and sediment core sampling method

The burial algae were sampled using a sediment core of $15 \mathrm{~cm}$ in length and a surface of $0.00679 \mathrm{~m}^{2}$ as illustrated on Figure 1. For each monitoring point and each site, ecological variables were measured on three cores (see further sections below). The cores were first positioned just to gently mark the algal mat. Before driving down the cores in mud, the algal mat was gently cut off all around the edge of the cores, in a way to avoid pulling down potential surface fragments and to avoid mixing them with burial fragments. The surface thalli were then collected manually inside the circle positioned core. It represents the layer named LO ( 0 to $0.5 \mathrm{~cm}$ depth; Figure $1 \mathrm{a}, \mathrm{c}$ ). Thus, the core was carefully pressed in sediment to collect the burial algae. Thereafter, cores were closed up and transported to the laboratory. Cores were stored at $4^{\circ} \mathrm{C}$ before their treatment (within the week). They were manually sliced into four layers of $3 \mathrm{~cm}$ thick (Figure $1 \mathrm{~b}$ and $\mathrm{c}$ ). The layer $\mathrm{L} 1$ corresponds to the three first centimeters of the core (from 0.5 to $3 \mathrm{~cm}$ ), the layer $L 2$, from 3 to $6 \mathrm{~cm}$, the layer L3 from 3 to $6 \mathrm{~cm}$, and the layer L4, from 9 to $12 \mathrm{~cm}$. 
Figure 1

Population biology (size of fragments and biomass)

Each separate mud core layer was washed with filtered seawater to recover the burial algae fragments before measurement of the biomass (fresh and dry weights, FW and DW respectively). The same protocol was done for the layer LO containing the algae from the surface of the mud. During sorting, fragment densities were set. The fragments longer than $3 \mathrm{~cm}$ were measured and the fragments shorter than $3 \mathrm{~cm}$ were counted. Fragment densities of $L 1$ to $L 4$ were classified into defined size classes adapted from Surget et al. (2017). Fragment densities of LO were not analysed as this was already done on quadrats at the same time and locations (see Surget et al. 2017). The dry biomass results and densities were represented by means \pm standard deviation (SD) and expressed in g. $\mathrm{m}^{-2}$ for the former and in $\mathrm{nb} \cdot \mathrm{m}^{-2}$ for the latter.

In order to guarantee time-independent data, care was also taken to sample different areas within each site at each sampling date. Data were compared in relation to sites and sampling dates.

Physiological Analyses

In vivo chlorophyll a fluorescence For analysis using Imaging PAM, other muddy cores were sampled in the site Faou together with ecological monitoring (as this site presented the most extensive mat of $A$. vermiculophyllum). The in vivo chlorophyll-a fluorescence analysis was performed $15 \mathrm{~h}$ after the field sampling and storage of cores at $4^{\circ} \mathrm{C}$ and kept in the dark. During layer preparation as fragment washing, care was taken to keep burial fragments in the dark. Before analysis, all thalli (buried and from the surface) were acclimated to the darkness for $30 \mathrm{~min}$.

Fragments of the same layer from several cores were placed in the air for fluorescence capture by Imaging PAM. Chlorophyll fluorescence imaging was carried out with a PAM imaging chlorophyll fluorometer (Open FluorCam FC 800-0, Photon System Instruments, Brno, Czech Republic) as described in Serôdio et al. (2013). Images were processed using the FluorCam7 software (Photon System Instruments, Brno, Czech Republic). During picture processing, the minimum threshold (allowing distinguishing color of the background from fluorescence of samples) was fixed to 200 (AU). To obtain three replicates with a minimum area of 20 pixels, analyses of L2 and L3 were pooled as the deepest fragments were less numerous and smaller than those from upper layers.

The ratio Fv/Fm, which corresponds to the optimal quantum yield of photosystem II (PSII) representing a measure of the maximum efficiency of PSII, was measured on fragments maintained in darkness using a $0.8 \mathrm{~s}$ saturating pulse of actinic light. The $\phi P S I I$, the effective quantum yield of PSII which then presents the efficiency of PSII photochemistry, was calculated according to Genty et al. (1989) on thalli at the end of each light-increasing step of 30 s each of the Rapid Light Curves (RLC) (9 light steps, ranging from 30 to $1049 \mu \mathrm{mol}$ photons $\mathrm{m}^{-2} \mathrm{~s}^{-1}$ ). $\phi P S I l$ was used to estimate the relative electron transport rate (rETR) (Gevaert et al. 2003), a proxy of photosynthesis, following the equations below: 
$\phi P S I I=\left(F m^{\prime}-F t\right) / F m^{\prime}$

rETR $=$ QPSII $x$ PAR

where PAR corresponds to recorded incident photosynthetic radiation monitored with a LiCor SA-190 quantum sensor.

The light-limited initial slope (a), the light-saturated relative maximum rate of relative electron transfer $\left(r_{\text {ETR }}\right.$ max , and the occurrence of photoinhibition $(\beta)$ were calculated by plotting rETR against irradiance and by fitting the data using the photosynthetic model of Platt (Platt and Gallegos 1980), model initially applied to phytoplankton. Corrected model of Walsby including also the occurrence of photoinhibition was tested (Nitschke et al. 2012) but the Platt model was favoured as it best fitted our data.

Respiration rate Respiration was measured at the laboratory on $A$. vermiculophyllum fragments from 4 cores sampled in the site Faou, during low tide in January 2017, in order to test the living potential of buried fragments. During layer preparation as fragment washing, i.e. elimination of mud and microorganisms at the surface of the alga, care was taken to keep burial fragments of $A$. vermiculophyllum in the dark. Fragments of the several layers were kept in seawater, simulating their suspension in the seawater column. An opaque chamber was used to estimate $\mathrm{CO}_{2}$ fluxes linked to the respiration of $A$. vermiculophyllum thalli. Changes in $\mathrm{CO}_{2}$ concentration (ppm) in the opaque chamber $(0.88 \mathrm{~L})$ were measured with an infrared gas analyser (LiCor Li-820) for $3 \mathrm{~min}$. $\mathrm{CO}_{2}$ concentrations were recorded using a data logger (LiCor Li-1400) every 1 s. $\mathrm{CO}_{2}$ flux was calculated as the slope of the linear regression of $\mathrm{CO}_{2}$ concentration $\left(\mu \mathrm{mol} . \mathrm{L}^{-1}\right.$ ) against time (s) and expressed in $\mu \mathrm{mol} . \mathrm{C} . \mathrm{m}^{-2} . \mathrm{h}^{-1}$ assuming a molar volume of $22.4 \mathrm{~L}$ at room temperature and ambient pressure.

Biochemical analyses

To complete our monitoring of Agarophyton vermiculophyllum in Brittany, biochemical analyses were performed on muddy cores sampled during low tide in the Faou site (identical method to the acquisition of population variables/characteristics) to test algal biochemical tolerance to burial. Samples were taken in September, for pigment quantification and metabolites. Macroalgae were treated as for population studies. Moreover, for these two analyses, layers L1 to L3 were pooled to have sufficient biomass of buried fragments. Thereby, two conditions were compared: surface vs silted thalli, i.e. algae distributed at the surface of the mud (fragments sampled in layer L0) vs buried fragments (algae sampled in layers L1L2-L3).

Pigments Several pigments, i.e. zeaxanthin (zea), violaxanthin (viola), antheraxanthin (anthera), chlorophyll-a (chl-a) and $\beta$-carotene ( $\beta$-car) were analysed by High Pressure Liquid Chromatography (HPLC) following the method developed by Schmid and Stengel (2015). Muddy cores on $A$. vermiculophyllum mat were sampled on the site Faou during September 2015. Frozen algal samples, kept at $-80^{\circ} \mathrm{C}$, were ground (Retch® MM400) in liquid nitrogen. Then, pigments were extracted from $100 \mathrm{mg}$ of ground samples in a $90 \%$ acetone solution, for 30 min with stirring, in the dark and at $4^{\circ} \mathrm{C}$. After 
centrifugation, a second extraction was performed during $15 \mathrm{~h}$. Supernatants were pooled before analyses. Pigments were analysed using an Eclipse XDB-C18 column (4.6 x 150 mm; $5 \mu \mathrm{m}$; Agilent) with a C18-guard-column. Chromatographic separation of pigments was performed as already published (Schmid and Stengel 2015; Lalegerie et al. 2019, 2020; Jégou et al. 2021). Acquisitions were performed using the software Chromeleon 6.60 (Dionex). After an identification based on absorption spectra of each peak and retention time of standards, pigment concentrations (expressed as $\mathrm{mg} . \mathrm{g}^{-1}$ ) were calculated using calibration curve (zea, viola, lut, anthera and $\beta$-car were ordered from DHI LAB products, Denmark, and chl-a standards from Sigma-Aldrich). When a pigment was not detected in the sample extract, pigment content was fixed to the half of the detection threshold content of the considered pigment to calculate sample pigment concentration, in order to carry out statistical analysis. Viola was detected in 5 replicates on 9 for surface fragments and in 2 replicates on 9 for silted fragments. Chl-c2 and fucoxanthin were detected in some samples linked to the presence of benthic diatom epiphytes on $A$. vermiculophyllum thalli. To go further in the physiological variables measured on our macroalga, xanthophylls on chl-a ratio were calculated as follows:

Xanthophylls $/$ chl- $a=\frac{(\text { viola }+ \text { anthera }+ \text { zea })}{c h l-a}$

Phycobiliprotein content was determined using a protocol adapted from Sun et al. (2009) and Roleda et al. (2012). Extraction was performed in the dark at $4^{\circ} \mathrm{C}$ on $100 \mathrm{mg} \mathrm{FW}$ with phosphate buffer $(0.1 \mathrm{M}, \mathrm{pH}=$ 6.8). After sonication for $15 \mathrm{~min}$, samples were centrifuged for $20 \mathrm{~min}$ at $4^{\circ} \mathrm{C}$. The obtained extracts were stored at $4^{\circ} \mathrm{C}$ in the dark until the absorbance was read at 455, 565, 592, 618 and $645 \mathrm{~nm}$ (POLARstar

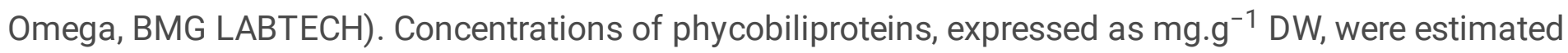
using the following equations from Beer and Eshel (1985) as follows:

$$
\begin{aligned}
& R-P E=\left[\left(A_{565}-A_{592}\right)-\left(A_{455}-A_{592}\right) \times 0.20\right] \times 0.12 \\
& R-P C=\left[\left(A_{618}-A_{645}\right)-\left(A_{592}-A_{645}\right) \times 0.50\right] \times 0.15
\end{aligned}
$$

where $\mathrm{A}=$ Absorbance; $\mathrm{R}-\mathrm{PE}=\mathrm{R}$-phycoerythrin; $\mathrm{R}-\mathrm{PC}=\mathrm{R}$-phycocyanin .

${ }^{1} \mathrm{H}$ qNMR spectroscopy ${ }^{1} \mathrm{H}$ NMR analyses were performed on twelve replicates (four cores with 3 replicates per core) gathered in parallel of pigments sampling. Algal samples were kept at $-80^{\circ} \mathrm{C}$ and grounded (Retch $\circledast$ MM400) in liquid nitrogen before being freeze-dried. About $15 \mathrm{mg}$ of homogeneous dried powder for each replicate was extracted with $800 \mu \mathrm{L} \mathrm{D}_{2} \mathrm{O}$ (deuterated $\mathrm{H}_{2} \mathrm{O}$, Euristo-Top, $\mathrm{D}_{2} \mathrm{O}$ 99.96\%). Sodium trimethylsilyl-propionate-d4 (TSP) was previously solubilized in $\mathrm{D}_{2} \mathrm{O}$ solvent (from 0.55 to $0.83 \mathrm{mg} \cdot \mathrm{mL}^{-1}$ depending on the sample series) and used as a standard. After centrifugation (mini centrifuge LMS, MCF2360), the supernatant was placed in NMR tubes (5-mm diameter). Spectral data were recorded at $25^{\circ} \mathrm{C}$ with a Bruker Avance III HD Spectrometer (Bruker BioSpin, Wissembourg, France), equipped with a TBI ${ }^{1} \mathrm{H} /\{\mathrm{BB}\} /{ }^{13} \mathrm{C}$ probehead. A typical ${ }^{1} \mathrm{H}$ spectrum consisted of 64 scans with a relaxation decay of $10 \mathrm{~s}$, needed for complete relaxation of the signals to properly conduct a quality 
integration. This methodology results in a high-resolution NMR spectrum and provides a fingerprint of the samples, i.e. an overview of the metabolites produced by the organism at the time of its collection (Simon et al. 2015; Kamio et al. 2016). Chemical shifts were expressed in ppm using TSP as the chemical shift internal reference (0 ppm) on Topspin software (Bruker Biospin). All recorded spectra were analysed with MestReNova 6.0.2 (Mestrelab Research S.L., Spain). All ${ }^{1} \mathrm{H}$ NMR spectra were phased and afterwards baseline-corrected using Bernstein polynomials. They were aligned on the TSP peak at $0 \mathrm{ppm}$.

For multivariate analysis, whole spectra were binned into buckets for the chemical shift region from 0.50 ppm to $6.50 \mathrm{ppm}$ and the size of each bin was $0.04 \mathrm{ppm}$. Once integrated, 110 area values were thus generated for each spectrum for further analysis. After logarithmic transformation, integration bucket data were scaled on whole spectra, i.e. intensity resulted from the spectra integration of the chemical shift region from 0.50 to $4.54 \mathrm{ppm}$ and from 4.98 to $5.50 \mathrm{ppm}$, excluding $\mathrm{H}_{2} \mathrm{O}$ signal. Multivariate correspondence analysis ( $\mathrm{COA}$ ) was performed on the dataset generated. Furthermore, relative concentrations of nitrogenous molecule pool as the ratio of carbonated to nitrogenous molecules pools were calculated as described by Surget et al. (2017) and Bondu et al. (2007).

The identification of the major metabolites detected on spectra was performed and signals assigned to an identified metabolite were integrated. The identification of floridoside, isethionic acid, taurine and alanine was confirmed according to Surget et al. (2017) and literature (Broberg et al. 1998; Simon-Colin et al. 2002; Gupta et al. 2013). Metabolite contents were compared between fragments from the upper layer of cores and silted fragments standardized on the TSP peak. Signals assigned to the identified

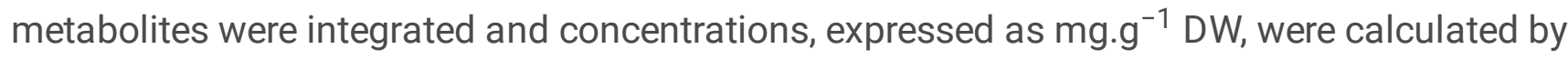
standardization on integral values of TSP signal $(9 \mathrm{H}, \mathrm{s})$. Indeed, floridoside concentrations were estimated from the integration of anomeric proton (at $5.17 \mathrm{ppm}, \mathrm{d}$ ), from the mean of integral value of the two $\mathrm{CH}_{2}$ groups (at 3.13-3.19 and at 3.93-3.98 ppm, t) for isethionic acid concentrations (as shown in Kerjean et al. 2007), from the mean of integral value on 2 protons chemical shift of $\mathrm{CH}_{2}$ (at 3.39-3.46 $\mathrm{ppm}, \mathrm{t}$ ) for the taurine, and finally from the methyl protons (at $1.47 \mathrm{ppm}, \mathrm{d}$ ) for alanine.

Statistics

Statistical analyses were performed with RStudio (v. 0.95.263) for R (v.3.1.3). All analyses were carried out in triplicate and results were expressed as means \pm standard deviation (SD). When the data met the requirements for parametric tests, they were analysed using multiple-way or one-way ANOVA (function of the number of factors) at a significance level of $95 \%$, followed by a Tukey post-hoc test. Data were transformed if necessary to respect homoscedasticity. When the data did not meet the requirements for an ANOVA, they were analysed using the two-way Scheirer Ray Hare test (SRH) (Sokal and Rohlf 1995), the one-way Kruskal-Wallis test (KW) or the Wilcoxon Mann Whitney test (WMW) depending of the number of factors and conditions, at a significance level of $95 \%$, followed by the multiple comparisons test after Kruskal-Wallis (kruskalmc function; pirgmess package).

\section{Results}


Biomass and density of populations

Our results illustrated the presence of silted fragments of $A$. vermiculophyllum at the three sites and throughout the monitoring period (Figures 2 and 3). Silted fragments represented from $15.57 \pm 10.16$ to $44.43 \pm 13.80 \%$ (minimum and maximum mean percentages between seasons) of the total biomass of $A$. vermiculophyllum mat (surface and buried thalli). They were mainly localized in the three first centimeters of the mud (layer L1) with a maximum of $40.09 \pm 11.86 \%$ and a minimum of $14.69 \pm 10.10 \%$ of buried algal biomass (percentages means observed in December 2013 and in June 2014 respectively). As it was expected, differences were observed between layers with a decrease in biomass with depth ( $\mathrm{SRH}, \mathrm{p}$-value $<0.05)$. But even if much less biomass was measured in deeper layers, algal thalli were observed all throughout the sediment column until 9 to $12 \mathrm{~cm}$ depth with 2.66 to $0.72 \%, 1.99$ to $0.01 \%$ and 0.55 to $0.02 \%$ of the total biomass located in layers L1, L2 and L3 respectively. Furthermore, differences between monitoring dates were observed with a decrease in fragment biomasses between December 2013 and December 2014 (with sites and layers pooled, SRH p-value < 0.05). Silted fragments represented on average $29.47 \pm 16.92 \%$ of biomass of the $A$. vermiculophyllum mat. They were mainly localized in the three first centimeters of the mud with, on average, $27.37 \pm 15.98 \%$ of the algal biomass located at the layer L1.

Figure 2

Fragments smaller than $3 \mathrm{~cm}$ were also significantly more abundant within silted fragments than other size classes and thus whatever the layer and the sampling date $(\mathrm{SRH}, \mathrm{p}$-value $<0.05$; Figure 3$)$. Density of fragments from $L 1$ presented differences among sites $(\mathrm{SRH}, \mathrm{p}$-value $<0.05)$ unlike deeper layers (L2 to $\mathrm{L} 4 ; \mathrm{SRH}$ p-value $>0.05$ ). On the other hand, few fragments shorter than $3 \mathrm{~cm}$ were interestingly sampled from 9 to $12 \mathrm{~cm}$ depth (L4) during the entire monitoring period (Figure 3 ).

Figure 3

Physiological responses of silted fragments

In vivo chlorophyll a fluorescence Results underlined a variation of the maximum quantum yield (Fv/Fm) measured especially between fragments from different core layers and between seasons (Figure 4). Indeed, fragments living at the surface of the mud (L0) exhibited the highest Fv/Fm (0.71 \pm 0.05$)$ along the monitoring period and were significantly different from layers L1 and L2-L3 with Fv/Fm of $0.62 \pm 0.07$ and $0.60 \pm 0.13$, respectively (when seasons were pooled, $\mathrm{SRH}, \mathrm{p}$-value $<0.001$ ). Moreover, this global trend was not similar for all sampling dates (when layers were pooled, $\mathrm{SRH}, \mathrm{p}$-value $=0.046$ ) as illustrated on Figure 4.

Figure 4

Indeed, the ratio Fv/Fm showed even no difference between the layers for two months (March and September 2014) between fragments living in depth and those distributed at the surface of the mud). 
The other photosynthetic parameters are presented in Table 1. Seasonal data were not pooled because a seasonal effect was detected for $\mathrm{rETR}_{\max }(\mathrm{SRH}, \mathrm{p}$-value $<0.05)$. Indeed, a significantly lower $r E T R_{\max }$ was exhibited in December 2014 for all layers compared to the other sampling dates (KW, $\mathrm{p}$-value $<0.001)$. On the contrary, the rETR $R_{\max }$ did not vary between the layers on overall data $(K W, p$-value $=0.064)$, indicating similar rETR $\mathrm{R}_{\text {max }}$ between fragments from the surface and buried fragments, even at $9 \mathrm{~cm}$ depth (see Table 1). On the other hand, $\alpha$ and $\beta$ parameters varied between layers (on the whole data, SRH, $p$-value $=$ 0.038 and $\mathrm{KW}, \mathrm{p}$-value $=0.022$ respectively). However, no clear pattern was observed among depths.

Table 1 Photosynthetic parameters $\left(\mathrm{rETR}_{\max }, \mathrm{a}\right.$ and $\left.\beta\right)$ of Agarophyton vermiculophyllum fragments from different depths (from layer L0 to L2-L3) and sampled at different dates, from December 2013 to December 2014. Values are means \pm SD $(n=3)$. No significant difference was detected between means of photosynthetic parameters $(p<0.05)$ according to Kruskal-Wallis test among layers for each season (LO: fragments from surface; L1: 0 to $3 \mathrm{~cm}$ depth; L2L3: 3 to $9 \mathrm{~cm}$ depth).

\begin{tabular}{|c|c|c|c|c|c|c|c|c|}
\hline \multirow{3}{*}{$\begin{array}{c}\text { Sampling date } \\
\text { dec-13 }\end{array}$} & \multirow{2}{*}{$\begin{array}{l}\text { Layer } \\
\text { LO }\end{array}$} & \multicolumn{2}{|r|}{$\alpha$} & \multicolumn{2}{|r|}{$\beta$} & \multicolumn{3}{|c|}{ rETRmax } \\
\hline & & 0.17 & 0.02 & \multicolumn{2}{|r|}{-} & \multicolumn{3}{|c|}{$>137.70$} \\
\hline & L1 & 0.16 & \pm 0.01 & 3.18 & \pm 0.28 & 124.89 & \pm & 12.22 \\
\hline & L2L3 & 0.20 & \pm 0.04 & 4.84 & \pm 2.22 & 110.00 & \pm & 25.68 \\
\hline \multirow{3}{*}{ march-14 } & LO & 0.18 & \pm 0.01 & 3.87 & \pm 0.72 & 113.53 & \pm & 24.54 \\
\hline & L1 & 0.12 & \pm 0.02 & 2.17 & \pm 0.91 & 144.75 & \pm & 29.29 \\
\hline & L2L3 & 0.23 & \pm 0.10 & 7.35 & \pm 2.36 & 100.76 & \pm & 28.68 \\
\hline \multirow{3}{*}{ june-14 } & LO & 0.20 & \pm 0.02 & 4.50 & \pm 0.83 & 109.14 & \pm & 10.26 \\
\hline & L1 & 0.14 & \pm 0.01 & 2.52 & \pm 0.38 & 141.04 & \pm & 21.38 \\
\hline & L2L3 & 0.18 & \pm 0.06 & 5.53 & \pm 3.74 & 95.97 & \pm & 31.28 \\
\hline \multirow{3}{*}{ sept-14 } & LO & 0.20 & \pm 0.00 & 3.82 & \pm 0.19 & 125.00 & \pm & 8.03 \\
\hline & L1 & 0.19 & \pm 0.01 & 3.62 & \pm 0.83 & 130.23 & \pm & 24.87 \\
\hline & L2L3 & 0.24 & \pm 0.04 & 6.73 & \pm 2.42 & 90.88 & \pm & 15.44 \\
\hline \multirow{3}{*}{ dec-14 } & LO & 0.22 & \pm 0.01 & 13.75 & \pm 1.81 & 40.44 & \pm & 4.65 \\
\hline & L1 & 0.20 & \pm 0.02 & 14.56 & \pm 1.34 & 33.79 & \pm & 5.50 \\
\hline & $\mathrm{L} 2 \mathrm{~L} 3$ & 0.10 & \pm 0.12 & 15.80 & \pm 7.40 & 8.05 & \pm & 13.95 \\
\hline
\end{tabular}

Table 1

Respiration rate All analyzed samples showed a respiration activity. However, $A$. vermiculophyllum fragments distributed at the surface of the mud presented a significantly higher respiration rate measured as $\mathrm{CO}_{2}$ flux than buried fragments $\left(48.71 \pm 13.85\right.$ and $8.55 \pm 5.50 \mu \mathrm{mol} \mathrm{CO} \mathrm{CO}^{-1} \cdot \mathrm{g}^{-1} \mathrm{FW}$, respectively; Ttest, $\mathrm{p}$-value $=0.037$ ).

Biochemical responses of silted fragments 
Pigment contents Surface versus buried thalli pigment contents are described in Table 2. A significant variation in pigment content was observed with depth, except for violaxanthin and R-phycoerythrin. The other xanthophyll pigments increased in silted fragments with antheraxanthin levels multiplied by 3.3 (WMW, p-value $=0.005$ ) and zeaxanthin increasing by one-third (WMW, p-value $=0.040)$. With burial, results illustrated an enrichment in chl-a (contents multiplied by around 2 , WMW, $p$-value $=0.003$ ) as in $\beta$ carotene (WMW, $\mathrm{p}$-value $=0.024)$ in $A$. vermiculophyllum fragments and a decrease in xanthophylls/chl-a ratio (WMW, p-value < 0.001). A decrease in R-phycocyanin was also observed with depth (WMW, $\mathrm{p}$-value $=0.003)$.

Table 2 Concentrations of pigment (expressed as $\mu \mathrm{g} \cdot \mathrm{g}^{-1} \mathrm{FW}$ or $\mathrm{mg} \cdot \mathrm{g}^{-1} \mathrm{FW}$ ) depending on the depth of $A$. vermiculophyllum fragments (at the surface of the mud or within the mud). Values are means $\pm S D(n=$ 9). Different letters indicate significant differences between means $(p<0.05)$ according to the Wilcoxon Mann-Whitney test.

Fragment Violaxanthin Antheraxanthin Zeaxanthin $\beta$-caroten condition

$$
\left(\mu \mathrm{g} \cdot \mathrm{g}^{-1} \mathrm{FW}\right) \quad\left(\mu \mathrm{g} \cdot \mathrm{g}^{-1} \mathrm{FW}\right) \quad\left(\mu \mathrm{g} \cdot \mathrm{g}^{-1} \mathrm{FW}\right)
$$

$\left(\mu \mathrm{g} \cdot \mathrm{g}^{-1} \mathrm{FW}\right)$

Surface

$0.22 \pm 0.17$

$0.34 \pm 0.28^{\mathrm{a}}$

$30.45 \pm 5.82^{\circ}$

$10.99 \pm 2.33^{\circ}$

Silted

$0.13 \pm 0.09$

$1.12 \pm 0.58^{b}$

$40.16 \pm 10.23^{b}$

$18.26 \pm 5.97$

Fragment

Chl- $a$

R-Phycoerythrin

R-Phycocyanin

Ratio

condition

$\left(\mu \mathrm{g} \cdot \mathrm{g}^{-1} \mathrm{FW}\right)$

$\left(\mathrm{mg} \cdot \mathrm{g}^{-1} \mathrm{FW}\right)$

(mg.g $\left.{ }^{-1} \mathrm{FW}\right) \quad$ Xanthophylls/Chl-a

Surface

$164.47 \pm 26.10^{a}$

$0.61 \pm 0.06$

$0.21 \pm 0.02^{a}$

$0.19 \pm 0.01$

Silted

$323.76 \pm 108.50^{b}$

$0.58 \pm 0.14$

$0.17 \pm 0.03^{b}$

$0.13 \pm 0.02$

Table 2

Algal major metabolites identification and quantification using ${ }^{1} \mathrm{H}$ qNMR analysis 
A Component Ordinate Analysis (COA) was conducted on data generated by the integration of bins on spectra since the dataset represented relative area ratios. COA analysis exhibited a clear pattern of differentiation on axis 1 depending on the burial of $A$. vermiculophyllum and allowed to discriminate buckets that contributed to this differentiation (Figure 5).

\section{Figure 5}

Axis 1 explained $37.5 \%$ of data variability and axis $219.1 \%$. The main bins which contribute to axis 1 were mainly buckets between 0.5 and $3 \mathrm{ppm}$, corresponding to chemical shift of aliphatic signals from amino acids in case of $\mathrm{D}_{2} \mathrm{O}$ extracts (Figure 5a). MANOVA analyses (conducted on COA coordinates) confirmed the significant difference between conditions, observed visually on COA (Figure 5b).

Figure 6

Buckets presenting the highest contribution to axis 1 were reported on superimposed spectra of silted and surface fragments (Figure 6) with the aim to identify peaks discriminating the two conditions. Moreover, examples of spectra were chosen in function of COA results with the aim to illustrate the more revealing spectra of silted and surface conditions (Figure 6). These buckets may correspond to a major peak on spectra. They also exhibited biomarkers of silted and surface conditions. In this way, major peaks were assigned to an identified metabolite, i.e. alanine, isethionic acid, taurine and floridoside, as shown in Figure 6. Estimated concentrations confirmed results obtained by COA with a significant variation of nitrogenous molecule pool between 0.5 and 3 ppm, and especially of the amino acid alanine (at 1.47 $\mathrm{ppm}$ ) that increased 3 times in silted fragments (Table 3). Furthermore, some buckets corresponded partly to the floridoside signal and effectively, estimated concentrations of floridoside decreased with the burial state of fragments $(T$-test, $T=-3.03, p$-value $=0.007$; Table 3 ).

Table 3 Metabolite concentrations (expressed as mg. $\mathrm{g}^{-1} \mathrm{DW}$ ) depending on the location of A. vermiculophyllum fragments (silted or at the surface of the mud), whatever the sampling date. Nitrogenous pool was represented as relative concentration (expressed in \%). Values are means \pm SD $(n=$ 11). Different letters indicate significant differences between means $(p<0.05)$ according to the Wilcoxon Mann-Whitney test or T-test. 


\begin{tabular}{lrlrl}
\hline Taurine & 104.43 & \pm 16.24 & 104.28 & \pm 13.25 \\
Floridoside & 217.36 & $\pm 61.86^{\mathrm{a}}$ & 147.87 & $\pm 47.74^{\mathrm{b}}$ \\
Isethionic acid & 142.38 & \pm 13.34 & 135.23 & \pm 18.52 \\
Alanine & 14.40 & $\pm 2.72^{\mathrm{a}}$ & $48.30 \pm 11.15^{\mathrm{b}}$ \\
$\mathrm{N}$ pool & 28.08 & $\pm 4.82^{\mathrm{a}}$ & $32.38 \pm 5.36^{\mathrm{b}}$ \\
$\mathrm{C} / \mathrm{N}$ ratio & 1.23 & $\pm 0.42^{\mathrm{a}}$ & $0.86 \pm 0.30^{\mathrm{b}}$
\end{tabular}

As a result, the $\mathrm{C} / \mathrm{N}$ ratio exhibited higher value in fragments from the surface of the mud than buried ones. On the other hand, isethionic acid and taurine showed no significant variation with the burial state of fragment ( $T$-test $T=-1.58$ and $T=-0.51$ with $p$-value $=0.13$ and $p$-value $=0.61$ respectively) as observed on the COA.

Table 3

\section{Discussion}

This study highlights the recurring capacity of the fragments from the red macroalga Agarophyton vermiculophyllum to live in sediment up to $12 \mathrm{~cm}$ deep in the mud in rias from Brittany (France). The occurrence of $A$. vermiculophyllum fragments in depth illustrated the perennial colonization of this macroalga in the studied rias of the Bay of Brest. These rias allowed a relative stability of $A$. vermiculophyllum mat and thus the establishment of a thick algal mat exhibiting a specific phenology compared to other invasive locations all around the world (Surget et al. 2017). Indeed, tidal current in Faou as well as in Penfoul and Moulin rias (Brittany, France) did not exceed $1.2 \mathrm{~m} . \mathrm{s}^{-1}$ at its maximal intensity during spring tides, estimated for a mean spring tide (corresponding to the French tidal coefficient of 95) as demonstrated by Guérin (2004). These velocities are the weakest tidal currents exhibited in the Bay of Brest, characterizing these shallow sheltered estuaries. The partial burial of $A$. vermiculophyllum in sediment was also observed in Danish populations from Horsens Fjord (Thomsen et al. 2007). Its burial tolerance was tested in situ by artificially burying thalli under 2 to $3 \mathrm{~cm}$ of sandy sediment in a mid-lagoon mudflat in the Hog Island Bay, in Virginia (Thomsen and McGlathery 2007). In the United States of America, this invasive macroalga exhibited a slower decomposition rate than two green macroalgae, Ulva curvata and Codium fragile, with a half-life of 9 days in a lagoon of Virginia. It was reported that even after a burial of several weeks, remaining fragments appeared structurally intact and healthy, joining our present field observations. Thereby, due to the tolerance of $A$. vermiculophyllum to burial, it was expected that important silted biomasses could be observed, as in our study where this buried biomass represented one third of the whole algal mat biomass. This biomass was highly 
fragmented and mainly composed of small fragments $(<3 \mathrm{~cm})$. This occurrence of $A$. vermiculophyllum thalli in depth within the sediment, as the significant buried biomasses it represented, have to be considered in the invasive potential of this non-native species.

In rias from the Bay of Brest, the observed algal burial life could not be only explained through mud deposition. This sedimentation phenomenon known to be important in protected rias may contribute to the burial of $A$. vermiculophyllum thalli but does not explain the occurrence of fragments down to 9 to 12 $\mathrm{cm}$ in depth in sediment. Indeed, sedimentation rates from 0 to $1 \mathrm{~cm} \cdot \mathrm{y}^{-1}$ were observed on the bare mud of Penfoul ria in 2004 (Fichaut et al., 2004). The specific morphology of this alga may facilitate a selfsilting process as known for the invasive seagrass Spartina alterniflora (Querné et al. 2012). Effectively, higher sedimentation rates could be encountered on areas colonized by $S$. alterniflora with rates varying between 0.5 and $2 \mathrm{~cm}^{-1} \mathrm{y}^{-1}$ during the same year (Fichaut et al. 2004). The presence of $A$. vermiculophyllum and its high fragmentation in depth could have several origins. Interestingly, it was shown that the colonization of mud by this invasive species leads to an increase in macrofauna densities and especially a higher abundance of the annelid Hediste diversicolor (Le Guillou 2012; Davoult et al. 2017). Thus, these high macrofauna densities may induce bioturbation of the mud and could enhance the fragmentation together with the fragment burial of $A$. vermiculophyllum. Thomsen et al. (2007) reported that the grazer Littorina littorea induced both a decrease in the algal biomass as well as an increase in the fragmentation rate of $A$. vermiculophyllum thalli. The mechanical burial of macroalgae in soft sediment linked to the bioturbation of polychaetes was reported in the literature for shallow coastal environments (Daly 1973; Hylleberg 1975; Nordström et al. 2006) such as deep-sea ones (Reichardt 1987). Additionally, Rossi et al. (2013) demonstrated that levels of macroalgal detritus in sandy sediments were six times greater in the presence of the lugworm Arenicola marina. These authors supposed that this species mechanically buried macroalgal fragments in their funnels, inducing an increase in half-time decomposition rate of the alga within the sediment (Rossi et al. 2013). Furthermore, the irrigation of burrows generated by Hediste diversicolor bioturbation and the induced sediment oxygenation influenced the decomposition rate of buried macroalgal fragments such as the brown seaweed Fucus serratus. As limited irrigated burrows induce a perennial burial, most macroalgal fragments may thereby remain intact in the sediment (Kristensen and Mikkelsen 2003). Indeed, bioturbation could explain the presence of some fragments in depth within the mud and could enhance the thallus fragmentation, as suggested by Surget et al. (2017). One should also hypothesize the potentiality of $A$. vermiculophyllum to resist to a bacterial degradation in producing antifouling molecules, and then controlling its epibionts community, as it was demonstrated in non-native populations of this species (Saha et al. 2016, 2020; Berke et al. 2020; Wang et al. 2021) and which could represent a key feature of the invasive potential of $A$. vermiculophyllum (Wang et al. 2017, 2021; Bonthond et al. 2020).

Additionally, several studies illustrated the low palatability of $A$. vermiculophyllum compared to other native macroalgae, as it was demonstrated for Ulva lactuca (Hu and Juan 2013). Currently, Ulva spp. were not developed luxuriantly on the muddy bottom of lower parts of rias in the Bay of Brest and $A$. 
vermiculophyllum is the dominant macrophyte of this ria with the invasive halophyte Spartina alterniflora (Surget et al. 2017). It was shown that $A$. vermiculophyllum could produce defense compounds, i.e oxylipins, acting as chemical feeding deterrents (Nylund et al. 2011; Rempt et al. 2012; Wang et al. 2021). This synthesis was induced by mechanical or grazing wounding. Interestingly, Hammann et al. (2013) underlined the capabilities of $A$. vermiculophyllum to produce defensive compounds by the up-regulation of feeding deterrents explaining the difference of palatability between native and invasive populations. On the other hand, herbivores are known to prefer feeding on nitrogen-enriched macrophytes with low C:N ratio since additive $\mathrm{N}$ may elicit their fitness (Mattson 1980) as reported for the snail Littorina sitkana (Van Alstyne et al. 2009) and the amphipod Gammarus locusta (Kraufvelin et al. 2006), this latter genus being part of the benthic macrofauna in Faou ria (Davoult et al. 2017). In the present study, burial fragments presented lower $\mathrm{C}: \mathrm{N}$ ratio (based on NMR spectra integration; Table 3 ) than thalli present at the surface of the mud. Indeed, it may contribute to a high thallus wounding by macrofauna under burial conditions. However, this hypothesis did not always explain differential feeding patterns and the production of chemical deterrent could also be determinant (Hammann et al. 2013). Therefore, we hypothesized that if grazed at the surface, the fragmentation of $A$. vermiculophyllum accelerated, facilitating the bioturbation force driving, and then resulting in the fragment burial of a few centimeters in the mud.

The buried $A$. vermiculophyllum thalli indeed appeared not degraded as shown by the different quantitative methods used in our study, i.e. in vivo chlorophyll-a fluorescence, measurement of respiration rate and pigments contents. Thus, we hypothesize that buried $A$. vermiculophyllum was physiologically active as it maintained its physiology and resisted any degradation after burial. Indeed, necrosis areas were observed at the interface air/mud while no necrosis has ever been detected on silted fragments (data not shown). Therefore, fragments observed within the mud were potentially still living and not consisted solely of detritic organic matter. After resuspension, buried fragments presented functional photosystems II (exhibited by in vivo chlorophyll a fluorescence results), indicating the physiological ability of $A$. vermiculophyllum to tolerate burial in muddy sediments. Positive respiration levels confirmed this hypothesis. However, the exposure of buried sediments to oxygenic conditions during the respiration measurements may induce a transport of oxygen-dependent electrons as it was supposed for cyanobacteria in stromatolites, prior to an induction of photosynthetic electron transport (Perkins et al. 2007). This electron transport could be due to Mehler reactions (water-water cycle), preventing an oxidative stress and limiting photoinhibition under light exposure (Asada 2000). Therefore, the waterwater cycle may induce an activation of electron transport within photosystems and may restore modulated fluorescence after prolonged burial as it was demonstrated in stromatolite communities after sandy burial (Perkins et al. 2007). These last authors thus proved the ability of cyanobacteria to activate and inactivate their photosynthetic processes to tolerate burial during several months (Perkins et al. 2007). Our present results thereby demonstrate a minima the activation of electron transport in photosystems I and II (linked to Mehler reactions) even if the activation of the photosynthesis cannot be confirmed. Further analysis, after exposition of silted fragments to several low light conditions would be necessary to corroborate this hypothesis. However, our results showed a reduction of only $13 \%$ of the 
photosynthetic efficiency with the burial, which demonstrates that our algal species was reactive to light after resuspension and exposure to light. Likewise, we showed that the variations of the other photosynthetic parameters ( $\mathrm{rETR}_{\max } \mathrm{a}$ and $\beta$ ) seemed to be not correlated with the burial and underlined the high physiological resistance of $A$. vermiculophyllum to these conditions. The slower respiration flux of buried fragments after resuspension in seawater illustrated the reduction of metabolic pathways induced by a burial life, suggesting a "state of dormancy" of $A$. vermiculophyllum within the mud. The physiology of this "state of dormancy" was not investigated in previous studies that reported a resistance of macroalgae to burial (Kamermans et al. 1998; Glasby et al. 2005; Kawamata et al. 2012). These studies mainly focused on the recovery of growth abilities of buried individuals after a return to favorable conditions. Interestingly, these buried fragments could represent a seedling bank, analogous to seed banks of terrestrial plants as it has already been described in a wide range of seaweeds genera, like Codium (Vidondo and Duarte 1998), Fucus (Creed et al. 1996), Turbinaria (Stiger and Payri 2005) and interestingly in the red macroalgae Gelidium and Gracilaria (Hoffmann and Santelices 1991).

Furthemore, our results exhibited variations of some metabolite contents in Agarophyton vermiculophyllum fragments in relation with burial condition. Firstly, the pigment composition and mainly xanthophylls of $A$. vermiculophyllum was similar to the ZEA-group of red macroalgae (Schubert and Garcia Mendoza 2008) including Gracilariales species, with zeaxanthin being the predominant carotenoid with traces of violaxanthin and antheraxanthin (Schubert et al. 2006; Schubert and Garcia Mendoza 2008; Torres et al. 2015). Traces of lutein have also been detected in samples of $A$. vermiculophyllum collected in Sweden (Roleda et al. 2012) but not in our samples. Although violaxanthin, antheraxanthin and zeaxanthin belong to the $V x$ cycle of xanthophylls allowing certain species of macroalgae to resist high light intensities, the presence of such a functional cycle in red macroalgae is still under debate (i.e. Schubert and Garcia Mendoza 2008; Esteban et al. 2009; Goss and Jacob 2010; Roleda et al. 2012). However a part of the pool of zeaxanthin can prevent the alga of the photoinhibition under strong light intensity or UV radiations (Schubert and Garcia Mendoza 2008; Roleda et al. 2012). In our study, the pigment concentrations between the surface and silted fragments could be explained by the conjunction of two complementary physiological phenomena: (1) an adaptation to the darkness to optimize the photon capture by antennae of photosystems and/or (2) the lack of growth of burial fragments compared to those living at the surface of the mud. Indeed, the growth of thalli at the surface could induce a dilution of intracellular metabolites like pigments. However, samples were gathered in September and an increase in biomass mat of $A$. vermiculophyllum was observed in June 2014 on this site (Surget et al. 2017), suggesting a growth of this alga in spring in Brittany as observed in its native range (Muangmai et al. 2014). Moreover, our study demonstrated an increase in chl-a with the burial life of $A$. vermiculophyllum together with a decrease in light availability, and a decrease in R-phycocyanin. Macler (1986) also observed some changes in the pigmentation of red algae and noticed also an increase in chlorophyll but an increase in phycobiliprotein levels under darkness conditions in nitrogen enriched algae as demonstrated in the red macroalga Gelidium coulteri. 
Finally, C:N ratio decreased in fragments distributed in depth into the mud, due to the increase in nitrogenous pool relative concentration, illustrating an increase in protein contents such as alanine, together with the decrease in floridoside level. Simon-Colin et al. (2004) demonstrated the high carbon photo-assimilation during floridoside biosynthesis under low salinities (i.e. hypoosmotic conditions) in another red macroalga Grateloupia turuturu. Moreover, Ekman et al. (1991) studied the chemical composition of Gracilaria chilensis (known before as G. sordida) under darkness with nutrient supplementation and observed the decline of $\mathrm{C}: \mathrm{N}$ ratio as well as of the concentration of floridoside under darkness and this decline was accentuated with nutrient supply. As photosynthesis was not possible for silted fragments, the decrease in floridoside content may be due to the fact that this osmolyte is a carbon reserve for the algal cell metabolism (Collén et al. 2004) and this C pool may be recycled within the alga for biosynthesis needs as suggested for another red macroalga Solieria chordalis (Bondu et al. 2007). Furthermore, Tyler et al. (2005) reported the ability of $A$. vermiculophyllum to uptake both urea and amino acids such as glycine under darkness conditions. In this way, nitrogenous molecules, mainly amino acids as alanine, increased in our red algal species to possibly maintain cell osmotic equilibrium and to compensate the decrease in the organic solute floridoside as it was already demonstrated in the red algal genera Gelidium and Bangia (Reed 1985; Macler 1986).

\section{Conclusions}

In conclusion, the results of the present study provided experimental evidence that $A$. vermiculophyllum was perennially present within muddy sediments in the rias of Brest and potentially in other invaded muddy flat. Furthermore, these quantitative data illustrated the living state and the acclimation of $A$. vermiculophyllum to burial. Potentially the dissemination of the buried biomass composed of small fragments present in the mud compared to longer fragments developed at the surface, could considerably enhance the propagation potential of A. vermiculophyllum in the case of resuspension of the algal mat due to anthropic perturbations or climatic events like storms. The algal development by vegetative reproduction was not dependent on the fragment size as it was reported that fragments of 1 $\mathrm{mm}$ survived and could develop to generate new thalli (Nyberg and Wallentinus 2009). Thereby, buried fragments could represent a reserve biomass of small fragments, i.e. a seedling bank as terrestrial seed bank, easily disseminated and may contribute significantly to the propagative abilities of $A$. vermiculophyllum at a local scale, especially in the Bay of Brest. Moreover, the burial resistance of $A$. vermiculophyllum may also contribute to its transoceanic migration and establishment through sediment transports.

\section{Declarations}

\section{Acknowledgements}

This study is part of a PhD project carried out by the first author at the Laboratoire des Sciences de I'Environnement Marin (LEMAR UMR6539) in the IUEM (UBO), under the supervision of the two last authors. It was supported by the Ministère de l'Education Nationale, de l'Enseignement Supérieur et de la 
Recherche (UBO funding for the first author) and Région Bretagne (ARED Labex Mer). This study was cofinanced with the support of the European Union ERDF - Atlantic Area Program and French ANR and is related to the research project INVASIVES (Era-net Seas-era. 2012-2016, ANR-12-SEAS-0002-01). Pigments analyses were financed by the IUEM project AL-PHOTOVEG (2016). Authors thank Joy Versterren for their fruitful assistance for the sampling and some sample analyses.

\section{Authors' contributions}

KLL, NP and VS-P supervised the PhD of the first author and SC supervised the Master course of MS. VS$P$ acquired the general financial support of the study and SC the financial support of the pigment analysis. GS, KLL, SC, GD, NP, and VS-P contributed to the conceptualization and design of the study. Material collection and preparation were performed by GS, KLL, GD, M-AP, IB, NP and VS-P. Data collection and analysis were performed by GS, KLL, NK, MS, SC, GD, M-AP, IB, DD, NP, and VS-P. The first draft of the manuscript was written by GS and GS, KLL, SC, GD, NP, DD, and VS-P: participated in the writing-review and editing. All authors contributed to the article and the improvement of the submitted version.

\section{Conflict of interest}

The authors declare no conflict of interest

\section{Data availability statement}

The data for this study are available by contacting the corresponding author

\section{Funding}

This study was funded by the Agence Nationale pour la Recherche (ANR-12-SEAS-0002-01) under the European call ERA-NET Seas-Era and the project INVASIVES.

\section{Consent to publication}

We consent to the publication of this manuscript dependent upon peer review and article acceptance.

\section{References}

1. Abreu MH, Pereira R, Sousa-Pinto I, Yarish C (2011) Ecophysiological studies of the non-indigenous species Gracilaria vermiculophylla (Rhodophyta) and its abundance patterns in Ria de Aveiro lagoon, Portugal. Eur J Phycol 46:453-464. https://doi.org/10.1080/09670262.2011.633174

2. Asada K (2000) The water-water cycle as alternative photon and electron sinks. Philos Trans R Soc B Biol Sci 355:1419-1431. https://doi.org/10.1098/rstb.2000.0703

3. Beer S, Eshel A (1985) Determining phycoerythrin and phycocyanin concentrations in aqueous crude extracts of red algae. Mar Freshw Res 36:785-792. https://doi.org/ 10.1071/MF9850785 
4. Bellorin AM, Oliveira MC, Oliveira EC (2004) Gracilaria vermiculophylla: A western Pacific species of Gracilariaceae (Rhodophyta) first recorded from the eastern Pacific. Phycol Res 52:69-79. https://doi.org/10.1111/j.1440-183.2004.00330.x

5. Berke SK, Keller EL, Needham CN, Salerno CR (2020) Grazer Interactions with Invasive Agarophyton vermiculophyllum (Rhodophyta): Comparisons to Related versus Unrelated Native Algae. Biol Bull 238: https://doi.org/145-153. 10.1086/709108

6. Bermejo R, MacMonagail M, Heesch S, Mendes A, Edwards M, Fenton O, Knöller K, Daly E, Morrison L (2020) The arrival of a red invasive seaweed to a nutrient over-enriched estuary increases the spatial extent of macroalgal blooms. Mar Env Res 158:104944. https://doi.org/10.1016/j.marenvres.2020.104944

7. Besterman AF, Karpanty SM, Pace ML (2020) Impact of exotic macroalga on shorebirds varies with foraging specialization and spatial scale. PLoS One 15:e0231337. https://doi.org/10.1371/journal.pone.0231337

8. Besterman AF, McGlathery KJ, Reidenbach MA, Wiberg PL, Pace ML (2021) Predicting benthic macroalgal abundance in shallow coastal lagoons from geomorphology and hydrologic flow patterns. Limnol Oceanogr 66:123-140. https://doi.org/10.1002/Ino.11592

9. Bondu S, Kervarec N, Deslandes E, Pichon R (2007) The use of HRMAS NMR spectroscopy to study the in vivo intra-cellular carbon/nitrogen ratio of Solieria chordalis (Rhodophyta). J Appl Phycol 20:673-679. https://doi.org/10.1007/978-1-4020-9619-8_28

10. Bonthond G, Bayer T, Krueger-Hadfield SA, Barboza FR, Nakaoka M, Valero M, Wang G, Künzel S, Weinberger $F(2020)$ How do microbiota associated with an invasive seaweed vary across scales?. Mol Ecol 29:2094-2108. https://doi.org/10.1111/mec.15470

11. Broberg A, Kenne L, Pedersén M (1998) In-situ identification of major metabolites in the red alga Gracilariopsis lemaneiformis using high-resolution magic angle spinning nuclear magnetic resonance spectroscopy. Planta 206:300-307. https://doi.org/10.1007/s004250050404

12. Byers JE, Gribben PE, Yeager C, Sotka EE (2012) Impacts of an abundant introduced ecosystem engineer within mudflats of the southeastern US coast. Biol Inv 14:2587-2600. https://doi.org/10.1007/s10530-012-0254-5

13. Collén PN, Camitz A, Hancock RD, Viola R, Pedersén M (2004) Effect of nutrient deprivation and resupply on metabolites and enzymes related to carbon allocation in Gracilaria tenuistipitata (Rhodophyta). J Phycol 40:305-314. https://doi.org/10.1111/j.1529-8817.2004.02174.x

14. Creed JC, Norton TA, Harding SP (1996) The development of size structure in a young Fucus serratus population. Eur J Phycol 31:203-209. https://doi.org/10.1080/09670269600651391

15. Daly JM (1973) Behavioural and secretory activity during tube construction by Platynereis dumerilii Aud and M. Edw. [Polychaeta: Nereidae]. J Mar Biol Assoc UK 53:521-529. https://doi.org/10.1017/S0025315400058732

16. Davoult D, Surget G, Stiger-Pouvreau V, Noisette F, Riera P, Stagnol D, Androuin T, Poupart N (2017) Multiple effects of Gracilaria vermiculophylla invasion on estuarine-mudflat functioning and 
diversity. Mar Env Res 131:227-235. https://doi.org/10.1016/j.marenvres.2017.09.020

17. Ekman P, Yu S, Pedersen M (1991) Effects of altered salinity, darkness and algal nutrient status on floridoside and starch content, a-galactosidase activity and agar yield of cultivated Gracilaria sordida. Br Phycol J 26:123-131. https://doi.org/10.1080/00071619100650091

18. Esteban R, Martinez B, Fernandez-Marin B, Maria Becerril J, García-Plazaola JI (2009) Carotenoid composition in Rhodophyta: insights into xanthophyll regulation in Corallina elongata. Eur J Phycol 44:221-230. https://doi.org/10.1080/09670260802439109

19. Fichaut B, Sparfel L, Suanez S (2004) Rapport d'étude sur la progression de la spartine (Spartina alterniflora) et dynamique sédimentaire en rade de Brest. Sites de Pont-Callec, du Pédel et de Mengleuz. Rapport de recherche] LETG-Brest UMR 6554 CNRS; Université de Bretagne Occidentale (UBO), 49 p. https://hal.archives-ouvertes.fr/hal-00071277

20. Genty B, Briantais J-M, Baker NR (1989) The relationship between the quantum yield of photosynthetic electron transport and quenching of chlorophyll fluorescence. Biochim. Biophys Acta BBA - Gen Subj 990:87-92. https://doi.org/10.1016/S0304-4165(89)80016-9

21. Gevaert F, Creach A, Davoult D, Migne A, Levavasseur G, Arzel P, Holl A, Lemoine Y (2003) Laminaria saccharina photosynthesis measured in situ: photoinhibition and xanthophyll cycle during a tidal cycle. Mar Ecol Prog Ser, 247:43-50. https://doi.org/10.3354/meps247043

22. Glasby TM, Gibson PT, Kay S (2005) Tolerance of the invasive marine alga Caulerpa taxifolia to burial by sediment. Aquat Bot 82:71-81. https://doi.org/10.1016/j.aquabot.2005.02.004

23. Goss R, Jakob T (2010) Regulation and function of xanthophyll cycle-dependent photoprotection in algae. Photosynth Res 106:103-122. https://doi.org/10.1007/s11120-010-9536-x

24. Guérin L (2004) La crépidule en rade de Brest: un modèle biologique d'espèce introduite proliférante en réponse aux fluctuations de l'environnement. PhD Université de Bretagne occidentale - Brest. https://tel.archives-ouvertes.fr/tel-00113505

25. Guillemin M-L, Akki SA, Givernaud T, Mouradi A, Valero M, Destombe C (2008) Molecular characterisation and development of rapid molecular methods to identify species of Gracilariaceae from the Atlantic coast of Morocco. Aquat Bot 89:324-330.

https://doi.org/10.1016/j.aquabot.2008.03.008

26. Gupta V, Thakur RS, Reddy CRK, Jha B (2013) Central metabolic processes of marine macrophytic algae revealed from NMR based metabolome analysis. RSC Adv 3:7037-7047. https://doi.org/10.1039/C3RA23017A

27. Gurgel CFD, Norris JN, Schmidt WE, Le HN, Fredericq S (2018) Systematics of the Gracilariales (Rhodophyta) including new subfamilies, tribes, subgenera, and two new genera, Agarophyton gen. nov. and Crassa gen. nov. Phytotaxa 374:1-23. https://doi.org/10.11646/PHYTOTAXA.374.1.1

28. Hammann M, Wang G, Rickert E, Boo SM, Weinberger F (2013) Invasion success of the seaweed Gracilaria vermiculophylla correlates with low palatability. Mar Ecol Prog Ser 486:93-103. https://doi.org/10.3354/meps10361 
29. Hoffmann AJ, Santelices B (1991) Banks of algal microscopic forms: Hypotheses on their functioning and comparisons with seed banks. Mar Ecol Prog Ser Oldendorf 79:185-194

30. Hu Z-M, Juan L-B (2013) Adaptation mechanisms and ecological consequences of seaweed invasions: a review case of agarophyte Gracilaria vermiculophylla. Biol Inv 16:967-976. https://doi.org/10.1007/s10530-013-0558-0

31. Hylleberg J (1975) Selective feeding by Abarenicola pacifica with notes on Abarenicola vagabunda and a concept of gardening in lugworms. Ophelia 14:113-137. https://doi.org/10.1080/00785236.1975.10421972

32. Jégou C, Connan S, Bihannic I, Cérantola S, Guérard F, Stiger-Pouvreau V (2021) Phlorotannin and Pigment Content of Native Canopy-Forming Sargassaceae Species Living in Intertidal Rockpools in Brittany (France): Any Relationship with Their Vertical Distribution and Phenology? Mar. Drugs 19:504-523. https://doi.org/ 10.3390/md19090504

33. Johnston CA, Lipcius RN (2012) Exotic macroalga Gracilaria vermiculophylla provides superior nursery habitat for native blue crab in Chesapeake Bay. Mar Ecol Prog Ser 467:137-146. https://doi.org/10.3354/meps09935

34. Kamermans P, Malta E, Verschuure JM, Lentz LF, Schrijvers L (1998) Role of cold resistance and burial for winter survival and spring initiation of an Ulva spp. (Chlorophyta) bloom in a eutrophic lagoon (Veerse Meer lagoon, The Netherlands). Mar Biol 131:45-51. https://doi.org/10.1007/s002270050295

35. Kameyama R, Nishihara GN, Kawagoe C, Terada R (2021) The effects of four stressors, irradiance, temperature, desiccation, and salinity on the photosynthesis of a red alga, Agarophyton vermiculophyllum (Gracilariales) from a native distributional range in Japan. J Appl Phycol 33:25612575. https://doi.org/10.1007/s10811-021-02469-1

36. Kamio M, Koyama M, Hayashihara N, Hiei K, Uchida H, Watanabe R, Suzuki T, Nagai H (2016) Sequestration of dimethylsulfoniopropionate (DMSP) and acrylate from the green alga Ulva spp. by the sea hare Aplysia juliana. J Chem Ecol 42:452-460. https://doi.org/10.1007/s10886-016-0703-1

37. Kawamata S, Yoshimitsu S, Tokunaga S, Kubo S, Tanaka T (2012) Sediment tolerance of Sargassum algae inhabiting sediment-covered rocky reefs. Mar Biol 159:723-733. https://doi.org/10.1007/s00227-011-1849-6

38. Kerjean V, Morel B, Stiger V, Bessieres M-A, Simon-Colin C, Magné C, Deslandes E (2007) Optimization of floridoside production in the red alga Mastocarpus stellatus: pretreatment, extraction and seasonal variations. Bot Mar 50:59-64. https://doi.org/10.1515/BOT.2007.005

39. Kim SY, Weinberger F, Boo SM (2010) Genetic data hint at a common donor region for invasive Atlantic and Pacific populations of Gracilaria vermiculophylla (gracilariales, Rhodophyta). J Phycol 46:1346-1349. https://doi.org/10.1111/j.1529-8817.2010.00905.x

40. Kraufvelin P, Salovius S, Christie H, Moy FE, Karez R, Pedersen MF (2006) Eutrophication-induced changes in benthic algae affect the behaviour and fitness of the marine amphipod Gammarus locusta. Aquat Bot 84:199-209. https://doi.org/10.1016/j.aquabot.2005.08.008 
41. Kristensen E, Mikkelsen OL (2003) Impact of the burrow-dwelling polychaete Nereis diversicolor on the degradation of fresh and aged macroalgal detritus in a coastal marine sediment. Mar Ecol Prog Ser 265:141-153. https://doi.org/10.3354/meps265141

42. Krueger-Hadfield SA, Byers JE, Bonthond G, Terada R, Weinberger EE, Sotka EE (2021) Intraspecific diversity and genetic structure in the widespread macroalga Agarophyton vermiculophyllum. $\mathrm{J}$ Phycol 57:1403-1410. https://doi.org/10.1111/jpy.13195

43. Krueger-Hadfield SA, Kollars NM, Strand AE, Byers JE, Shainker SJ, Terada R, Greig TW, Hammann M, Murray DC, Weinberger EE, Sotka EE (2017) Genetic identification of source and likely vector of a widespread marine invader. Ecol Evol 7:4432-4447. https://doi.org/10.1002/ece3.3001

44. Lalegerie F, Stiger-Pouvreau V, Connan S (2020) Temporal variation in pigment and mycosporine-like amino acid composition of the red macroalga Palmaria palmata from Brittany (France): hypothesis on the MAA biosynthesis pathway under high irradiance. J Applied Phycol 32:2641-2656. https://doi.org/10.1007/s10811-020-02075-7

45. Lalegerie F, Lajili S, Bedoux G, Taupin L, Stiger-Pouvreau V, Connan S (2019) Photo-protective compounds in red macroalgae from Brittany: Considerable diversity in mycosporine-like amino acids (MAAs). Mar Environ Res 147:37-48. https://doi.org/10.1016/j.marenvres.2019.04.001

46. Le Guillou E (2012) Effets d'espèces invasives sur les peuplements de faune benthiques des milieux estuaires : cas de l'algue rouge Gracilaria vermiculophylla. Master Thesis, Université de Bretagne Occidentale. 20p.

47. Macler BA (1986) Regulation of carbon flow by nitrogen and light in the red alga, Gelidium coulteri. Plant Physiol 82:136-141. https://doi.org/10.1104/pp.82.1.136

48. Martínez-Lüscher J, Holmer M (2010) Potential effects of the invasive species Gracilaria vermiculophylla on Zostera marina metabolism and survival. Mar Env Res 69:345-349. https://doi.org/10.1016/j.marenvres.2009.12.009

49. Mattson WJJ (1980) Herbivory in relation to plant nitrogen content. Annu Rev Ecol Syst 11:119-161. https://doi.org/10.1146/annurev.es.11.110180.001003

50. Muangmai N, Vo TD, Kawaguchi S (2014) Seasonal fluctuation in a marine red alga, Gracilaria vermiculophylla (Gracilariales, Rhodophyta), from Nokonoshima Island, Southern Japan. J Fac Agric Kyushu Univ 59:243-248. https://doi.org/doi/10.5109/1467624

51. Nettleton JC, Mathieson AC, Thornber C, Neefus CD, Yarish C (2013) Introduction of Gracilaria vermiculophylla (Rhodophyta, Gracilariales) to New England, USA: Estimated Arrival Times and Current Distribution. Rhodora 115:28-41. https://doi.org/10.3119/12-07

52. Nitschke U, Connan S, Stengel DB (2012) Chlorophyll a fluorescence responses of temperate Phaeophyceae under submersion and emersion regimes: a comparison of rapid and steady-state light curves. Photosynth Res 114:29-42. https://doi.org/10.1007/s11120-012-9776-z

53. Nordström M, Bonsdorff E, Salovius S (2006) The impact of infauna (Nereis diversicolor and Saduria entomon) on the redistribution and biomass of macroalgae on marine soft bottoms. J Exp Mar Biol Ecol 333:58-70. https://doi.org/10.1016/j.jembe.2005.11.024 
54. Nyberg CD (2007) Introduced marine macroalgae and habitat modifiers: their ecological role and significant attributes. Doctoral theses, Göteborg University. Faculty of Science. pp. 62. http://hdl.handle.net/2077/4719

55. Nyberg CD, Wallentinus I (2009) Long-term survival of an introduced red alga in adverse conditions. Mar Biol Res 5:304-308. https://doi.org/10.1080/17451000802428159

56. Nylund GM, Weinberger F, Rempt M, Pohnert G (2011) Metabolomic assessment of induced and activated chemical defence in the invasive red alga Gracilaria vermiculophylla. PLOS ONE 6:e29359. https://doi.org/10.1371/journal.pone.0029359

57. Perkins RG, Kromkamp JC, Reid RP (2007) Importance of light and oxygen for photochemical reactivation in photosynthetic stromatolite communities after natural sand burial. Mar Ecol Prog Ser 349:23-32. https://doi.org/10.3354/meps07087

58. Platt T, Gallegos CL (1980) Modelling Primary Production, in: Falkowski PG (Ed.), Primary Productivity in the Sea, Environmental Science Research. Springer US, pp. 339-362.

59. Querné J, Ragueneau O, Poupart N (2012) In situ biogenic silica variations in the invasive salt marsh plant, Spartina alterniflora: A possible link with environmental stress. Plant Soil 352:157-171. https://doi.org/10.1007/s11104-011-0986-5

60. Ramus AP, Silliman BR, Thomsen MS, Long ZT (2017) An invasive foundation species enhances multifunctionality in a coastal ecosystem. Proc Natl Acad Sci US A 114, 8580-8585. https://doi.org/10.1073/pnas.1700353114

61. Ramus AP, Long ZT (2016) Producer diversity enhances consumer stability in a benthic marine community. J Ecol 104:572-579. https://doi.org/10.1111/1365-2745.12509

62. Reed RH (1985) Osmoacclimation in Bangia atropurpurea (Rhodophyta, Bangiales): the osmotic role of floridoside. Br Phycol J 20:211-218. https://doi.org/10.1080/00071618500650221

63. Reichardt WT (1987) Burial of Antarctic macroalgal debris in bioturbated deep-sea sediments. Deep Sea Res. Part Oceanogr Res Pap 34:1761-1770. https://doi.org/10.1016/0198-0149(87)90024-0

64. Rempt M, Weinberger F, Grosser K, Pohnert G (2012) Conserved and species-specific oxylipin pathways in the wound-activated chemical defense of the noninvasive red alga Gracilaria chilensis and the invasive Gracilaria vermiculophylla. Beilstein J Org Chem 8:283-289. https://doi.org/10.3762/bjoc.8.30

65. Roleda MY, Nyberg CD, Wulff A (2012) UVR defense mechanisms in eurytopic and invasive Gracilaria vermiculophylla (Gracilariales, Rhodophyta). Physiol Plant 146:205-216. https://doi.org/10.1111/j.1399-3054.2012.01615.x

66. Roleda MY, Dethleff D (2011) Storm-generated sediment deposition on rocky shores: Simulating burial effects on the physiology and morphology of Saccharina latissima sporophytes, Marine Biology Research 7(3):213-223. https://doi.org/10.1080/17451000.2010.497189

67. Rossi F, Gribsholt B, Gazeau F, Santo VD, Middelburg JJ (2013) Complex effects of ecosystem engineer loss on benthic ecosystem response to detrital macroalgae. PLOS ONE 8:e66650. https://doi.org/10.1371/journal.pone.0066650 
68. Rueness J (2005) Life history and molecular sequences of Gracilaria vermiculophylla (Gracilariales, Rhodophyta), a new introduction to European waters. Phycologia 44:120-128. https://doi.org/10.2216/0031-8884

69. Saha M, Ferguson RMW, Dove S, Künzel S, Meichssner R, Neulinger SC, Petersen FO, Weinberger F (2020) Salinity and time can alter epibacterial communities of an invasive seaweed. Front Microbiol 10:2870. https://doi.org/10.3389/fmicb.2019.02870

70. Saha M, Wiese J, Weinberger F, Wahl M (2016) Rapid adaptation to controlling new microbial epibionts in the invaded range promotes invasiveness of an exotic seaweed. J Ecol 104:969-978. https://doi.org/10.1111/1365-2745.12590

71. Saunders GW (2009) Routine DNA barcoding of Canadian Gracilariales (Rhodophyta) reveals the invasive species Gracilaria vermiculophylla in British Columbia. Mol Ecol Res 9:140-50. https://doi.org/10.1111/j.1755-0998.2009.02639.x

72. Schmid M, Stengel DB (2015) Intra-thallus differentiation of fatty acid and pigment profiles in some temperate Fucales and Laminariales. J Phycol 51:25-36. https://doi.org/10.1111/jpy.12268

73. Schubert N, García-Mendoza E (2008) Photoinhibition in red algal species with different carotenoid profiles. J Phycol 44:1437-1446. https://doi.org/10.1111/j.1529-8817.2008.00590.x

74. Schubert N, García-Mendoza E, Pacheco-Ruiz I (2006) Carotenoid composition of marine red algae. J Phycol 42:1208-1216. https://doi.org/10.1111/j.1529-8817.2006.00274.x

75. Serôdio J, Ezequiel J, Frommlet J, Laviale M, Lavaud J (2013) A method for the rapid generation of non-sequential light-response curves of chlorophyll fluorescence. Plant Physiol 163:1089-1102. https://doi.org/10.1104/pp.113.225243

76. Sfriso A, Buosi A, Wolf MA, Sfriso AA (2020) Invasion of alien macroalgae in the Venice Lagoon, a pest or a resource? Aquat Inv 15:245-270. https://doi.org/10.3391/ai.2020.15.2.03

77. Sfriso A, Maistro S, Andreoli C, Moro I (2010) First record of Gracilaria vermiculophylla (Gracilariales, Rhodophyta) in the Po Delta lagoons, Mediterranean Sea (Italy). J Phycol 46:1024-7. https://doi.org/10.1111/j.1529-8817.2010.00893.x

78. Simon G, Kervarec N, Cérantola S (2015) HRMAS NMR Analysis of Algae and Identification of Molecules of Interest via Conventional 1D and 2D NMR: Sample Preparation and Optimization of Experimental Conditions. In: Stengel D, Connan S (eds) Natural Products From Marine Algae. Humana Press, New York, NY. pp 191-205. https://doi.org/10.1007/978-1-4939-2684-8_12

79. Simon-Colin C, Kervarec N, Pichon R, Deslandes E (2004) NMR ${ }^{13}$ C-isotopic enrichment experiments to study carbon-partitioning into organic solutes in the red alga Grateloupia doryphora. Plant Physiol Biochem 42:21-26. https://doi.org/10.1016/j.plaphy.2003.10.006

80. Simon-Colin C, Kervarec N, Pichon R, Deslandes E (2002) Complete ${ }^{1} \mathrm{H}$ and ${ }^{13} \mathrm{C}$ spectral assignment of floridoside. Carbohydr Res 337:279-280. https://doi.org/10.1016/S0008-6215(01)00312-3

81. Sokal RR, Rohlf FJ (1995) Biometry: The principles and practice of statistics in biological research. Third ed. Freeman WH and $\mathrm{C}^{\circ}$, pp. 887. 
82. Stiger V, Payri CE (2005) Natural settlement dynamics of a young population of Turbinaria ornata and phenological comparisons with older populations. Aquat Bot 81:225-243. https://doi.org/10.1016/j.aquabot.2004.12.005

83. Stiger-Pouvreau V, Thouzeau G (2015) Marine species introduced on the French Channel-Atlantic coasts: A review of main biological invasions and impacts. Open J Ecol 5(5):227-257. https://doi.org/10.4236/oje.2015.55019

84. Sun L, Wang S, Gong X, Zhao M, Fu X, Wang L (2009) Isolation, purification and characteristics of Rphycoerythrin from a marine macroalga Heterosiphonia japonica. Protein Expr Purif 64:146-154. https://doi.org/10.1016/j.pep.2008.09.013

85. Surget G, Le Lann K, Delebecq G, Kervarec N, Donval A, Poullaouec M-A, Bihannic I, Poupart N, StigerPouvreau V (2017) Seasonal phenology and metabolomics of the introduced red macroalga Gracilaria vermiculophylla, monitored in the Bay of Brest (France). J Appl Phycol 29:2651-2666. https://doi.org/10.1007/s10811-017-1060-3

86. Thomsen MS, McGlathery KJ (2007) Stress tolerance of the invasive macroalgae Codium fragile and Gracilaria vermiculophylla in a soft-bottom turbid lagoon. Biol Invasions 9:499-513. https://doi.org/10.1007/s10530-006-9043-3

87. Thomsen MS, McGlathery K (2006) Effects of accumulations of sediments and drift algae on recruitment of sessile organisms associated with oyster reefs. J Exp Mar Biol Ecol 328:22-34. https://doi.org/10.1016/j.jembe.2005.06.016

88. Thomsen MS, McGlathery K (2005) Facilitation of macroalgae by the sedimentary tube forming polychaete Diopatra cuprea. Estuar Coast Shelf Sci 62:63-73. https://doi.org/10.1016/j.ecss.2004.08.007

89. Thomsen MS, Ramus AP, Long ZT, Silliman BR (2019) A seaweed increases ecosystem multifunctionality when invading bare mudflats. Biol Inv 21:27-36. https://doi.org/10.1007/s10530018-1823-z

90. Thomsen MS, Stæhr PA, Nejrup LB, Schiel DR (2013) Effects of the invasive macroalgae Gracilaria vermiculophylla on two co-occurring foundation species and associated invertebrates. Aquat Inv 8:133-145. http://dx.doi.org/10.3391/ai.2013.8.2.02

91. Thomsen MS, Stæhr PA, Nyberg CD, Schwaerter S, Krause-Jensen D, Silliman BR (2007) Gracilaria vermiculophylla (Ohmi) Papenfuss, 1967 (Rhodophyta, Gracilariaceae) in northern Europe, with emphasis on Danish conditions, and what to expect in the future. Aquat Invasions 2:83-94. http://dx.doi.org/10.3391/ai.2007.2.2.1

92. Torres PB, Chow F, Santos DY (2015) Growth and photosynthetic pigments of Gracilariopsis tenuifrons (Rhodophyta, Gracilariaceae) under high light in vitro culture. J Applied Phycol 27:12431251. https://doi.org/10.1007/s10811-014-0418-z

93. Tyler AC, McGlathery KJ, Macko SA (2005) Uptake of urea and amino acids by the macroalgae Ulva lactuca (Chlorophyta) and Gracilaria vermiculophylla (Rhodophyta). Mar Ecol Prog Ser 294:161172. https://doi.org/10.3354/meps294161 
94. Van Alstyne KL, Pelletreau KN, Kirby A (2009) Nutritional preferences override chemical defenses in determining food choice by a generalist herbivore, Littorina sitkana. J Exp Mar Biol Ecol 379:85-91. https://doi.org/10.1016/j.jembe.2009.08.002

95. Vidondo B, Duarte CM (1998) Population structure, dynamics, and production of the Mediterranean macroalga Codium bursa (Chlorophyceae). J Phycol 34:918-924. https://doi.org/10.1046/j.15298817.1998.340918.x

96. Volaric MP, Berg P, Reidenbach MA (2019) An invasive macroalga alters ecosystem metabolism and hydrodynamics on a tidal flat. Mar Ecol Prog Ser 628:1-16. https://doi.org/10.3354/meps13143

97. Wang G, Ren $Y$, Wang S, Hou M, Weinberger F (2021) Shifting chemical defence or novel weapons? A review of defence traits in Agarophyton vermiculophyllum and other invasive seaweeds. Marine Life Science and Technology https://doi.org/10.1007/s42995-021-00109-8

98. Wang S, Wang G, Weinberger F, Bian D, Nakaoka M, Lenz M (2017) Anti-epiphyte defences in the red seaweed Gracilaria vermiculophylla: non-native algae are better defended than their native conspecifics. J. Ecol 105:445-457. https://doi.org/10.1111/1365-2745.12694

99. Weinberger F, Buchholz B, Karez R, Wahl M (2008) The invasive red alga Gracilaria vermiculophylla in the Baltic Sea: adaptation to brackish water may compensate for light limitation. Aquat Biol 3:251264. https://doi.org/10.3354/ab00083

100. Yokoya NS, Kakita H, Obika H, Kitamura T (1999) Effects of environmental factors and plant growth regulators on growth of the red alga Gracilaria vermiculophylla from Shikoku Island, Japan. In: Kain JM, Brown MT, Lahaye M (Eds), Sixteenth International Seaweed Symposium, Developments in Hydrobiology. Springer Netherlands, pp 339-347. https://doi.org/10.1023/A:1017072508583

\section{Figures}




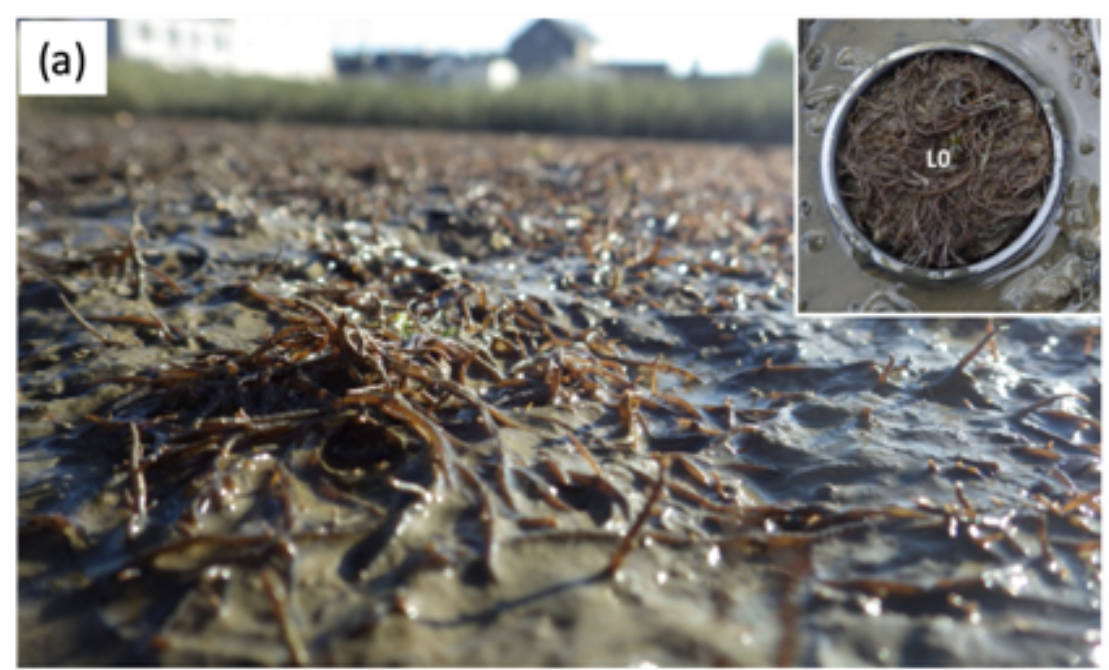

(b)

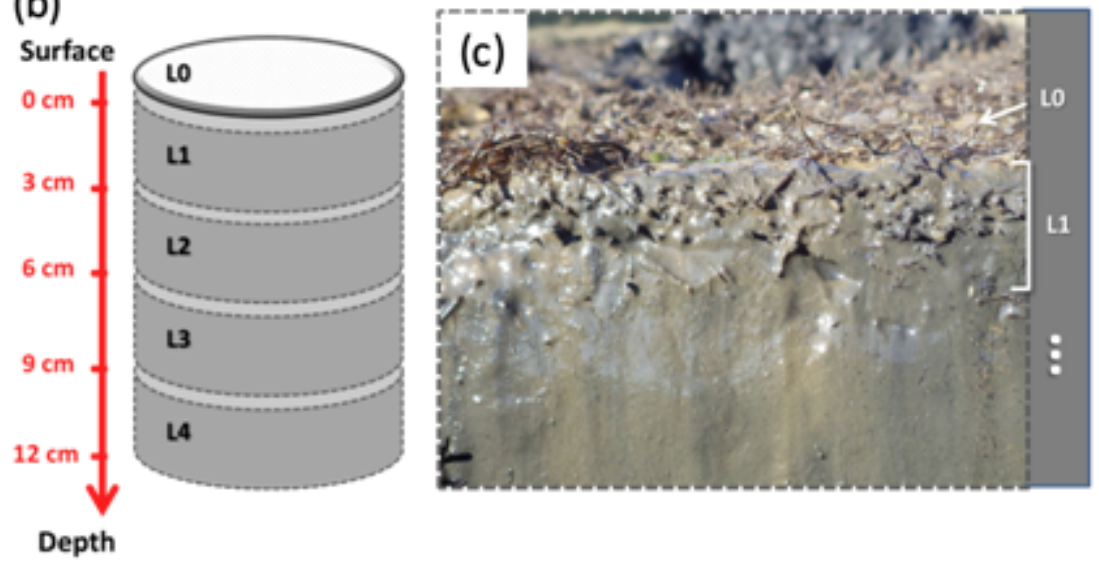

\section{Figure 1}

(a) Entangled mat of Agarophyton vermiculophyllum in the Faou site with a view of core during sampling (at top right). (b) Schematic representation of a mud core with the several mud layers from L1 to L4 (L1: layer from 0.5 to $3 \mathrm{~cm}$ depth, L2: layer from 3 to $6 \mathrm{~cm}$, L3: layer from 6 to $9 \mathrm{~cm}, \mathrm{~L} 4$ : from 9 to $12 \mathrm{~cm}$ ) and the surface layer, LO. (c) Cross section within the mud on the algal mat illustrating the thalli burial. Photographs were taken in February 2016. 


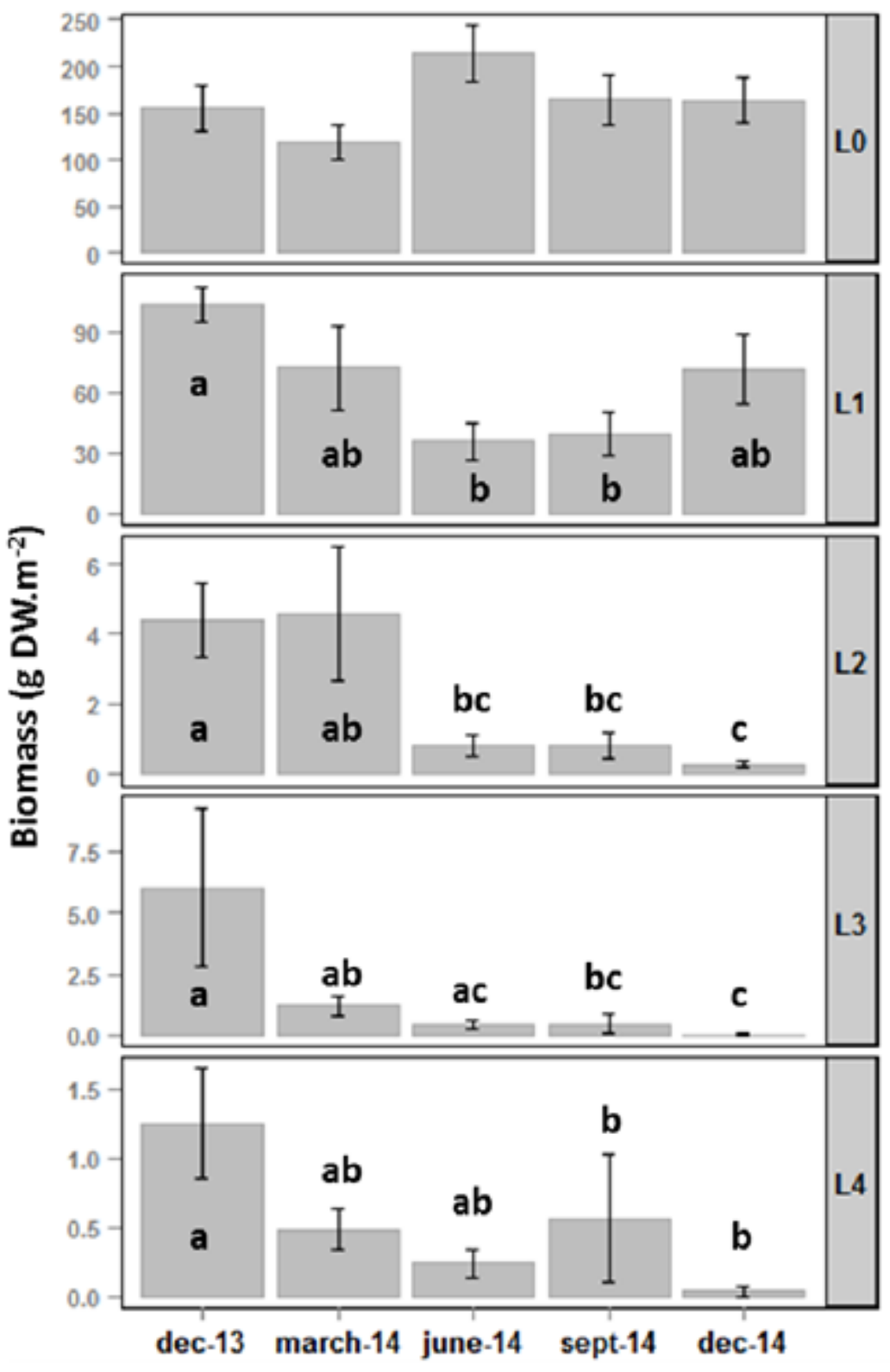

Figure 2

Biomass ( $\mathrm{g} \mathrm{DW} . \mathrm{m}^{-2}$ ) variations of Agarophyton vermiculophyllum fragments according to their depth in sediment (between mud cores layers) from December 2013 to December 2014. Represented results are means $\pm S D(n=9)$. Sites data were pooled as no site effect was detected $(S R H, p>0.05)$. Different letters indicate significant differences between means $(p<0.05)$ according to a Kruskal-Wallis test, followed by non-parametric post-hoc tests. Please note the different scales for the vertical axes. L0: fragments from the surface; L1: fragments from 0 to $3 \mathrm{~cm}$ depth; L2: fragments from 3 to $6 \mathrm{~cm}$ depth; L3: fragments from 6 to $9 \mathrm{~cm}$ depth; L4: fragments from 9 to $12 \mathrm{~cm}$ depth. 


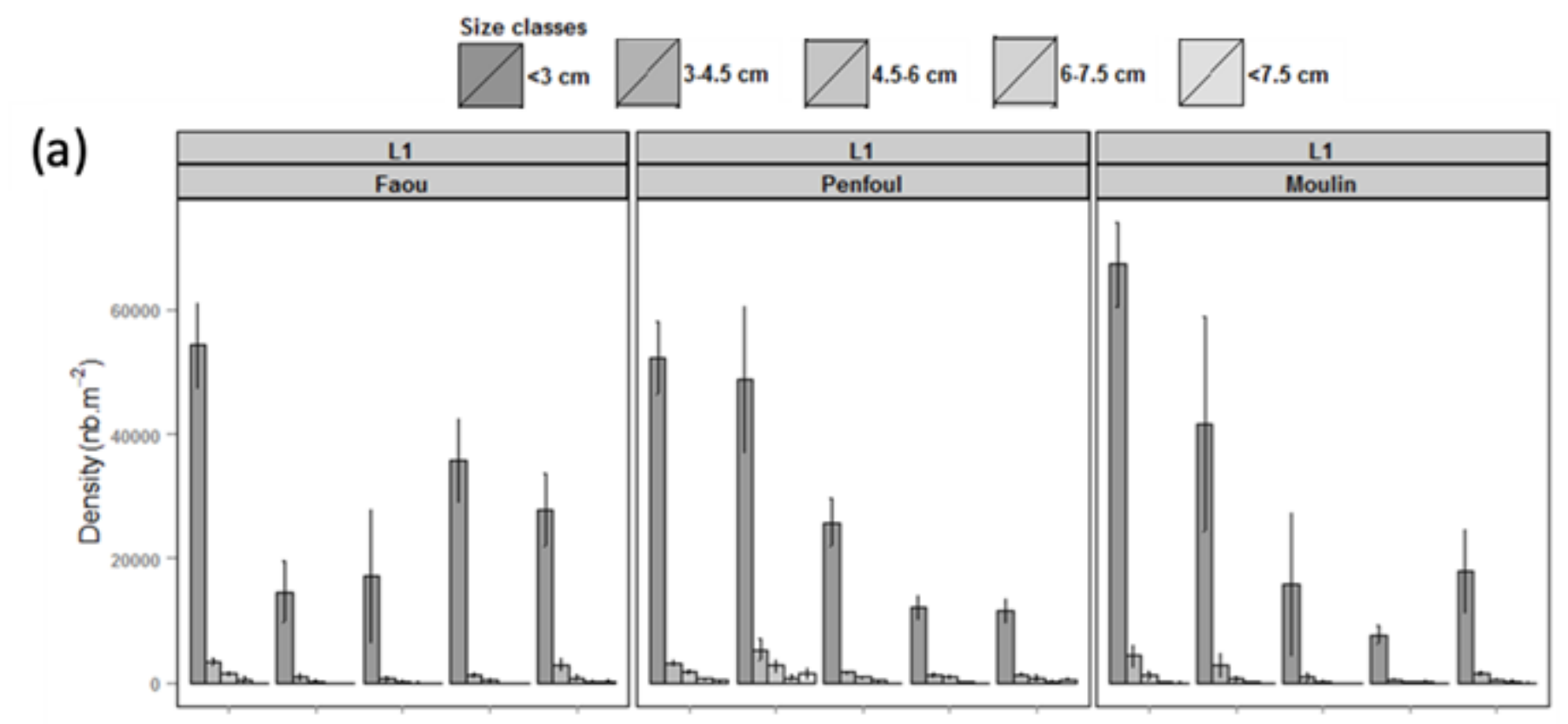

(b)

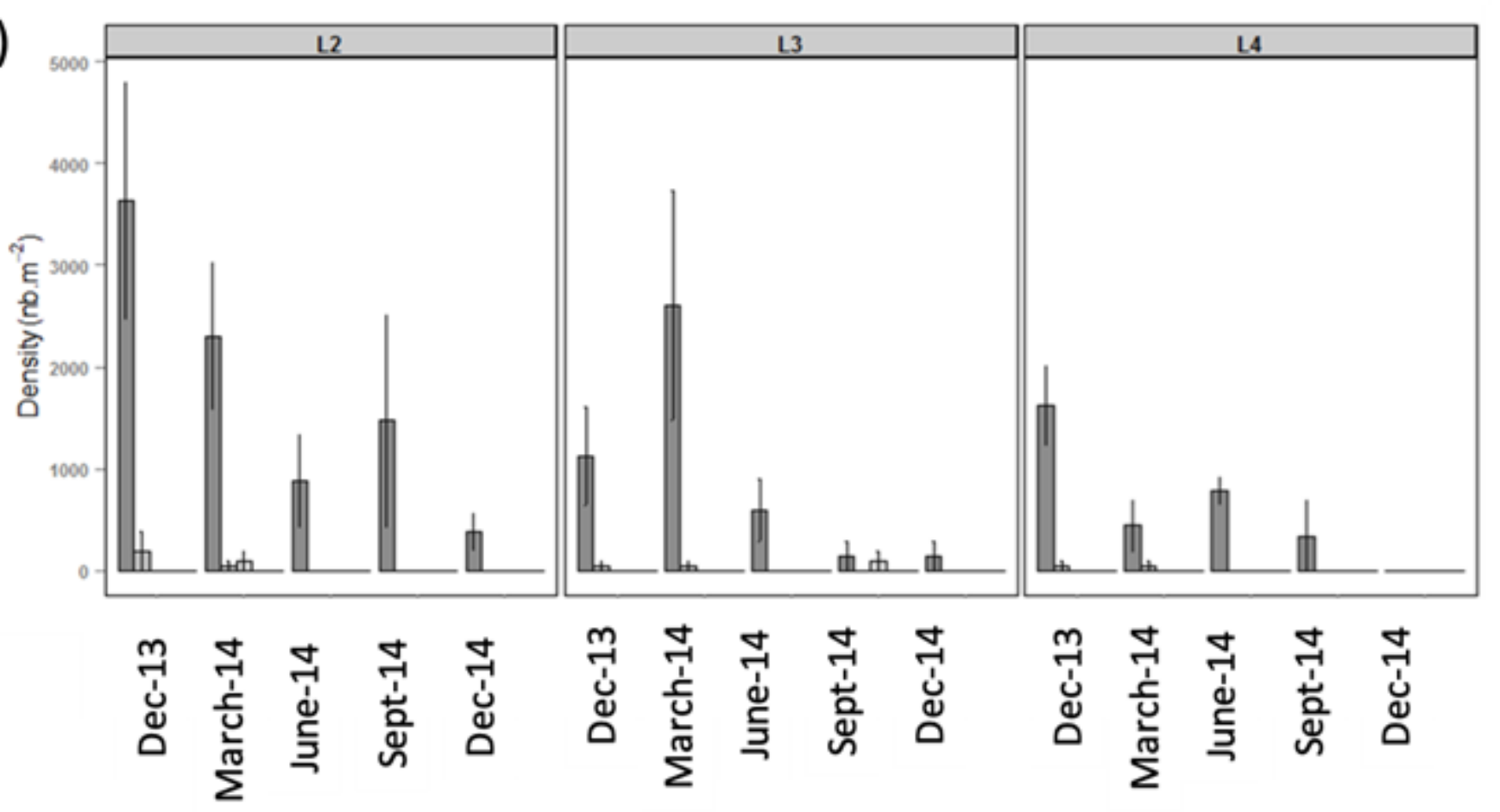

Figure 3

Fragment density (nb. $\mathrm{m}^{-2}$ ) variations of the red macroalga Agarophyton vermiculophyllum depending on their silting depth (mud layers) and their size classes during the monitoring period, from December 2013 to December 2014. Results are expressed as means \pm SD. (a) Density variations of fragment size classes from the layer L1 (from 0 to $3 \mathrm{~cm}$ depth) for each site $(n=3)$ as a significant site effect was detected (SRH, p-value < 0.05). (b) Density variations of fragment size classes from the layers $L 2$ (3 to $6 \mathrm{~cm}$ depth), L3 (6 to $9 \mathrm{~cm}$ depth) and L4 (9 to $12 \mathrm{~cm}$ depth) when sites are pooled ( $\mathrm{n}=9)$ as no significant site effect was observed $(\mathrm{SRH}, \mathrm{p}$-value $>0.05)$. 

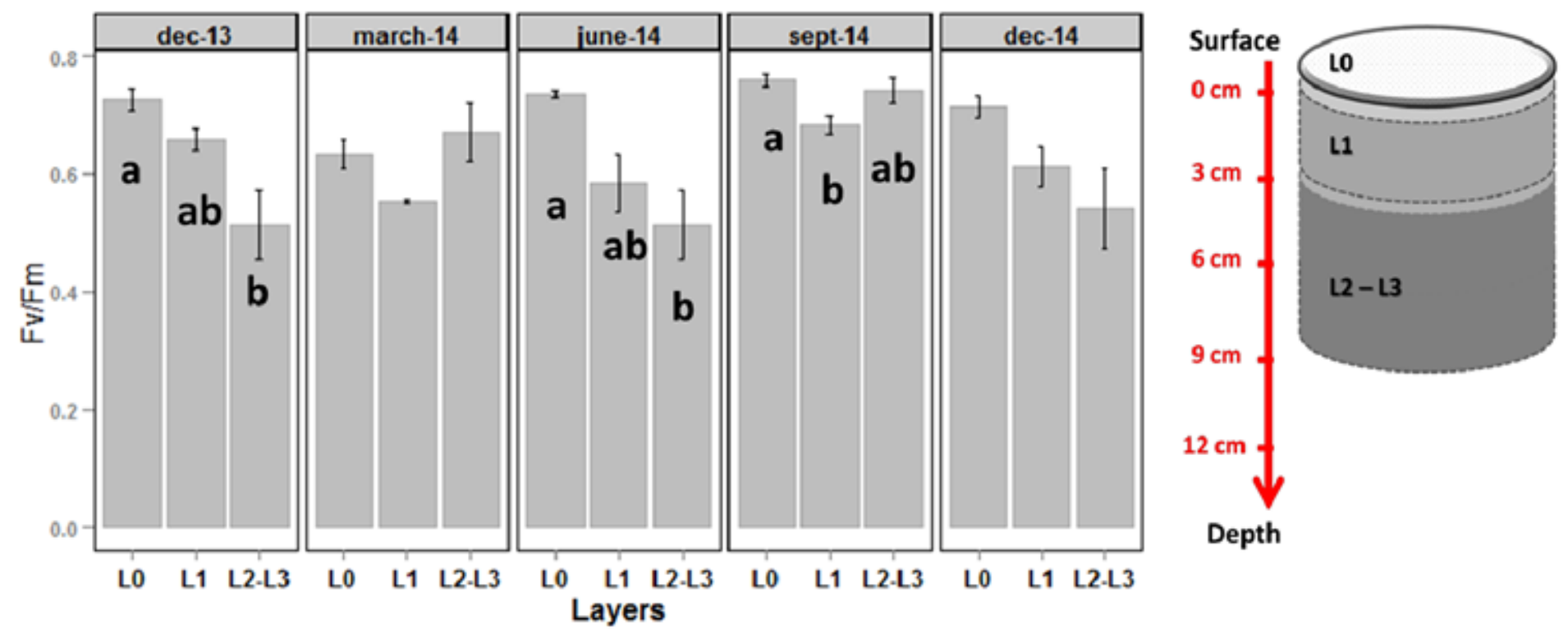

\section{Figure 4}

Fv/Fm or maximum quantum yield of Agarophyton vermiculophyllum fragments as a function of depth (from layer L0 to L3) and seasons (from December 2013 to December 2014). L0: fragments from the surface of the mud; L1: 0 to $3 \mathrm{~cm}$ depth; L2-L3: 3 to $9 \mathrm{~cm}$ depth. Results are expressed as means \pm SD ( $\mathrm{n}$ $=3)$. Different letters indicate significant differences between means $(p<0.05)$ according to a KruskalWallis test or one-way Anova, followed by the adequate post-hoc tests.
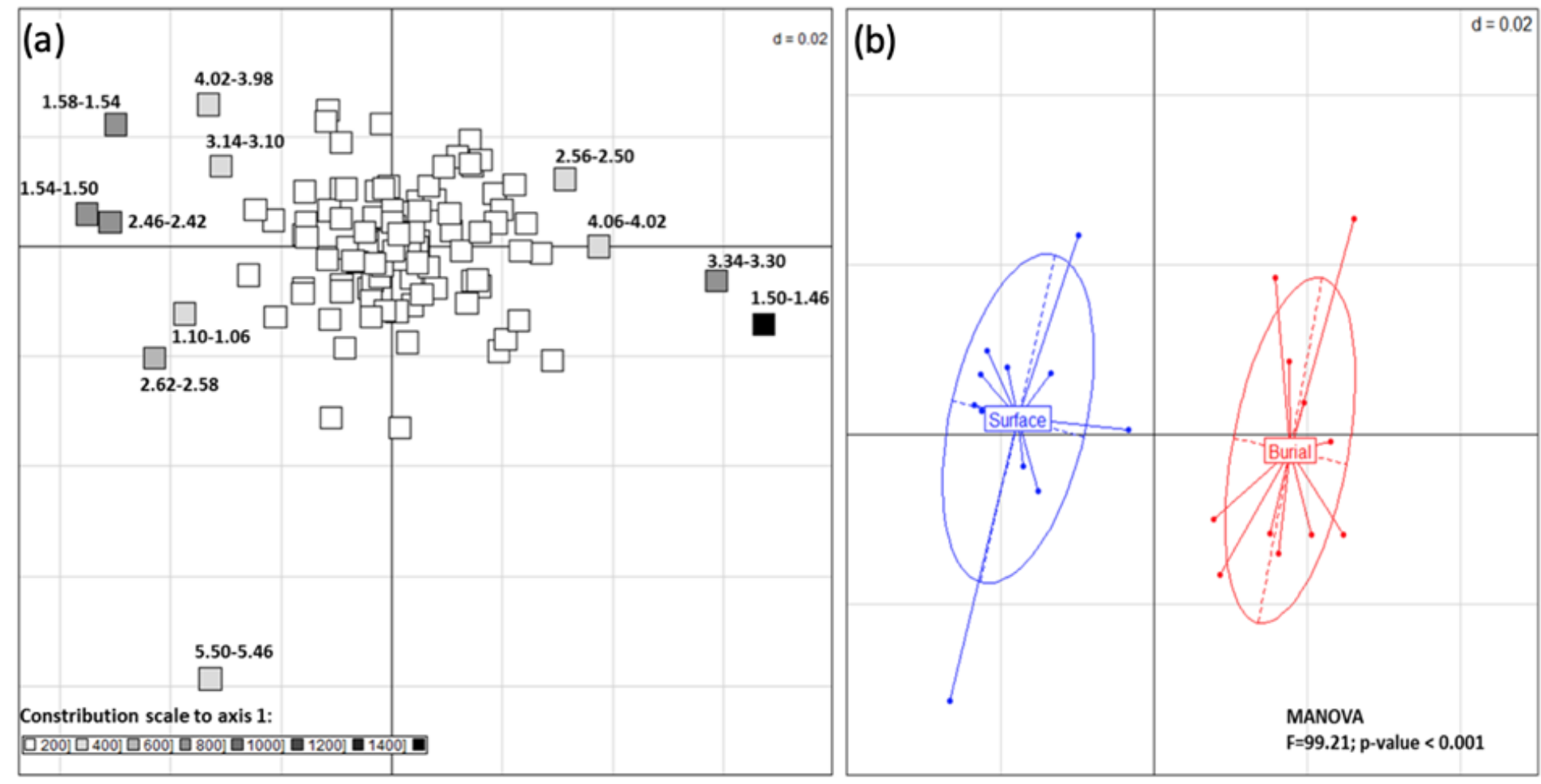

Figure 5 
Component ordinate Analyses (COA) of integrated bins on Agarophyton vermiculophyllum spectra depending on the burial of algal fragments. (a) COA correlation plot of 110 integrated bins. Each square represented a bin and the square color intensity was linked to the variable contribution on axis 1 . The chemical shift range of bins that contributed more than $4 \%$ to axis 1 (colored in grey) was noticed. (b) COA score plot of individuals depending on the burial of algal fragments. Ellipses with a confidence level of $99 \%$ were drawn around considered factor, ie. fragment condition (surface versus burial).

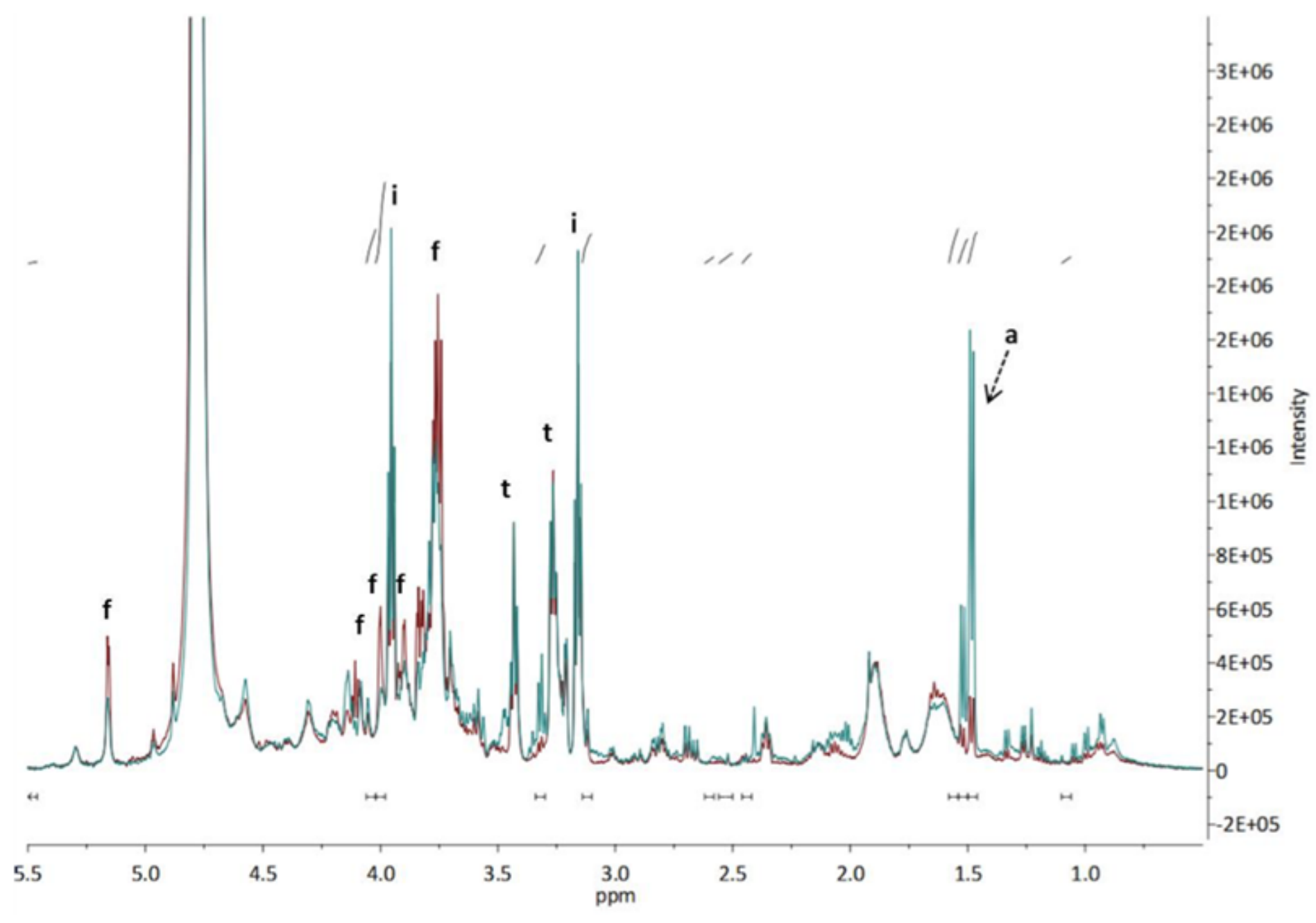

\section{Figure 6}

Superimposed ${ }^{1} \mathrm{H}$ NMR spectra of $\mathrm{D}_{2} \mathrm{O}$ extracts of a silted fragment (in blue-green) and a fragment living at the surface of the mud (in dark red) of Agarophyton vermiculophyllum. Black segments under spectra lines represented bins that mainly contributed to axis 1 of $\mathrm{COA}$, colored in grey more or less intense on the Fig. 5a. Bold letters indicate the identified metabolite corresponding to the spectral signal(s) with i for isethionic acid, $t$ for taurine, $f$ for floridoside and a for alanine. 